San Jose State University

SJSU ScholarWorks

Mineta Transportation Institute Publications

$6-2020$

\title{
What Do Americans Think About Federal Tax Options to Support Transportation? Results from Year Eleven of a National Survey
}

Asha W. Agrawal

San Jose State University, asha.weinstein.agrawal@sjsu.edu

Hilary Nixon

San Jose State University, hilary.nixon@sjsu.edu

Follow this and additional works at: https://scholarworks.sjsu.edu/mti_publications

Part of the Policy Design, Analysis, and Evaluation Commons, and the Transportation Commons

\section{Recommended Citation}

Asha W. Agrawal and Hilary Nixon. "What Do Americans Think About Federal Tax Options to Support Transportation? Results from Year Eleven of a National Survey" Mineta Transportation Institute Publications (2020). https://doi.org/10.31979/mti.2020.2007

This Report is brought to you for free and open access by SJSU ScholarWorks. It has been accepted for inclusion in Mineta Transportation Institute Publications by an authorized administrator of SJSU ScholarWorks. For more information, please contact scholarworks@sjsu.edu. 
SJSU UNIVERSITY SATE

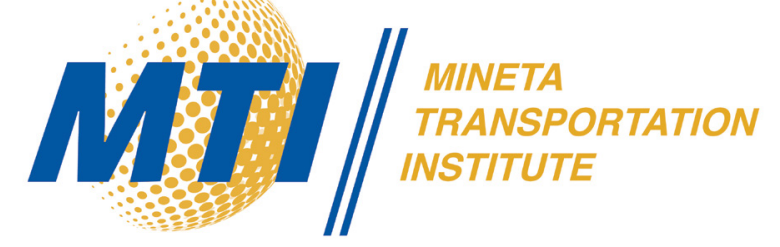

What Do Americans Think About Federal Tax Options to Support Transportation?

Results from Year Eleven of a National Survey

Asha Weinstein Agrawal, Ph.D.

Hilary Nixon, Ph.D.

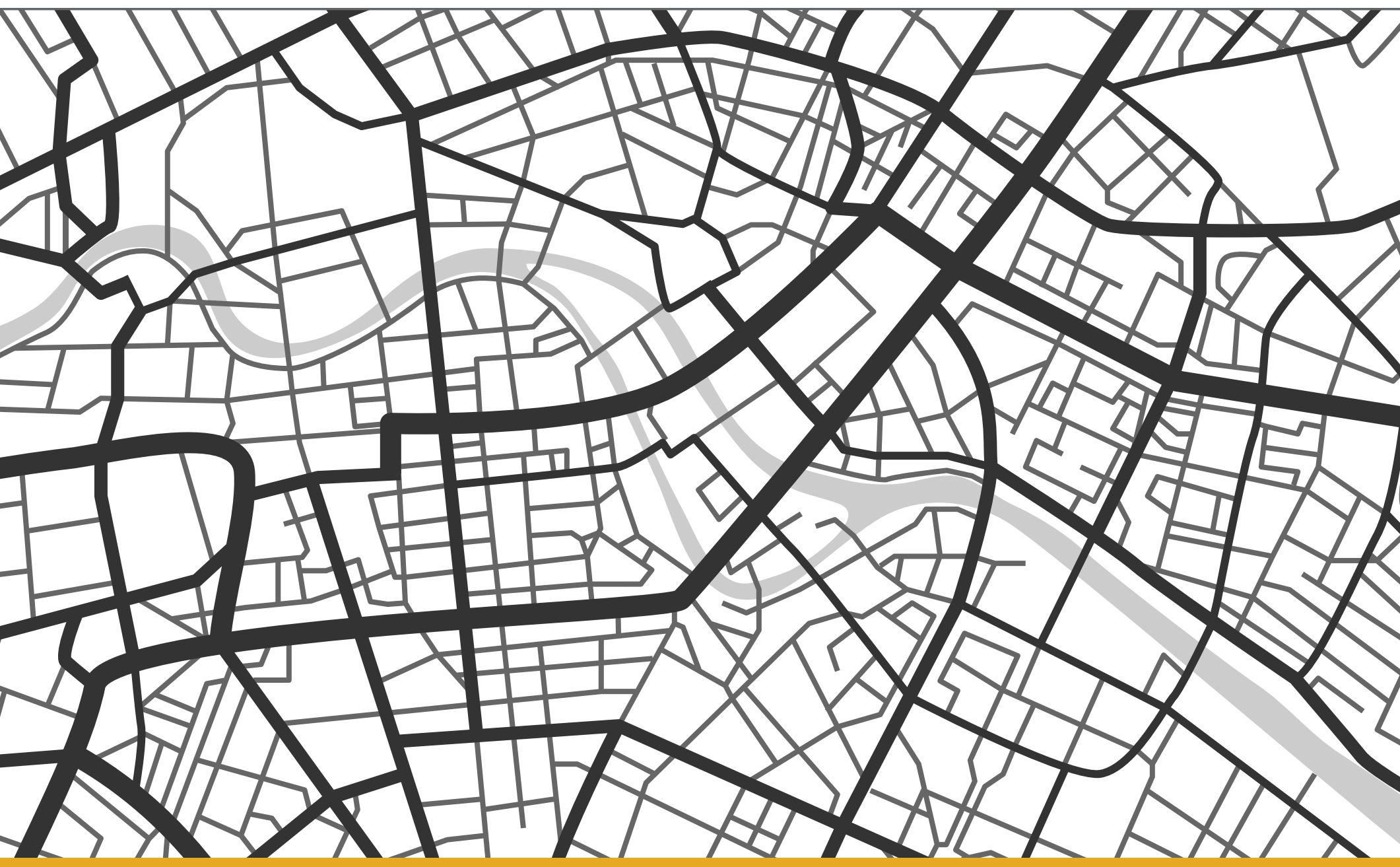




\section{MINETA TRANSPORTATION INSTITUTE \\ LEAD UNIVERSITY OF \\ Mineta Consortium for Transportation Mobility}

Founded in 1991, the Mineta Transportation Institute (MTI), an organized research and training unit in partnership with the Lucas College and Graduate School of Business at San José State University (SJSU), increases mobility for all by improving the safety, efficiency, accessibility, and convenience of our nation's transportation system. Through research, education, workforce development, and technology transfer, we help create a connected world. MTI leads the four-university Mineta Consortium for Transportation Mobility, a Tier I University Transportation Center funded by the U.S. Department of Transportation's Office of the Assistant Secretary for Research and Technology (OST-R), the California Department of Transportation (Caltrans), and by private grants and donations.

MTl's transportation policy work is centered on three primary responsibilities:

\section{Research}

MTI works to provide policy-oriented research for all levels of government and the $P$ rivate sector to foster the development of optimum surface transportation systems. Research areas include: bicycle and pedestrian issues; financing public and private sector transportation improvements; intermodal connectivity and integration; safety and security of transportation systems; sustainability of transportation systems; transportation / land use / environment; and transportation planning and policy development. Certified Research Associates conduct the research. Certification requires an advanced degree, generally a Ph.D., a record of academic publications, and professional references. Research projects culminate in a peer-reviewed publication, available on TransWeb, the MTI website (http://transweb.sjsu.edu).

\section{Education}

The Institute supports education programs for students seeking a career in the development and operation of surface transportation systems. MTI, through San José State University, offers an AACSBaccredited Master of Science in Transportation Management and graduate certificates in Transportation Management,Transportation Security, and High-Speed Rail Management that serve to prepare the nation's transportation managers for the 2 I st century. With the active assistance of the California Department of Transportation (Caltrans), MTI delivers its classes over a state-of-the-art videoconference network throughout the state of California and via webcasting beyond, allowing working transportation professionals to pursue an advanced degree regardless of their location. To meet the needs of employers seeking a diverse workforce, MTl's education program promotes enrollment to under-represented groups.

\section{Information and Technology Transfer}

MTI utilizes a diverse array of dissemination methods and media to ensure research results reach those responsible for managing change. These methods include publication, seminars, workshops, websites, social media, webinars, and other technology transfer mechanisms. Additionally, MTI promotes the availability of completed research to professional organizations and journals and works to integrate the research findings into the graduate education program.MTI's extensive collection of transportation- related publications is integrated into San José State University's world-class Martin Luther King, Jr. Library.

\section{Disclaimer}

The contents of this report reflect the views of the authors, who are responsible for the facts and accuracy of the information presented herein. This document is disseminated in the interest of information exchange. The report is funded, partially or entirely, by a grant from the U.S. Department of Transportation's University Transportation Centers Program. This report does not necessarily reflect the official views or policies of the U.S. government, State of California, or the Mineta Transportation Institute, who assume no liability for the contents or use thereof. This report does not constitute a standard specification, design standard, or regulation. 
REPORT 20-26

\title{
WHAT DO AMERICANS THINK ABOUT FEDERAL TAX OPTIONS TO SUPPORT TRANSPORTATION? RESULTS FROM YEAR ELEVEN OF A NATIONAL SURVEY
}

\author{
Asha Weinstein Agrawal, Ph.D. \\ Hilary Nixon, Ph.D.
}

June 2020

A publication of

Mineta Transportation Institute

Created by Congress in 1991

College of Business

San José State University

San José, CA 95192-0219 


\section{TECHNICAL REPORT DOCUMENTATION PAGE}

1. Report No. 20-26

4. Title and Subtitle

What Do Americans Think About Federal Tax Options to Support Transportation?

Results from Year Eleven of a National Survey

7. Authors

Asha Weinstein Agrawal, Ph.D. (https://orcid.org/0000-0003-2328-0263) Hilary Nixon, Ph.D. (https://orcid.org/0000-0001-5378-3473)

9. Performing Organization Name and Address

Mineta Transportation Institute

College of Business

San José State University

San José, CA 95192-0219

12. Sponsoring Agency Name and Address

U.S. Department of Transportation

Office of the Assistant Secretary for

Research and Technology

University Transportation Centers Program

1200 New Jersey Avenue, SE

Washington, DC 20590
3. Recipient's Catalog No.

5. Report Date

June 2020

6. Performing Organization Code

8. Performing Organization Report CA-MTI-2007

10. Work Unit No.

11. Contract or Grant No. 69A3551747127

13. Type of Report and Period Covered Final Report

14. Sponsoring Agency Code

15. Supplemental Notes

DOI: 10.31979/mti.2020.2007

\section{Abstract}

This report summarizes the results from the eleventh year of a national public opinion survey asking U.S. adults questions related to their views on federal transportation taxes. A nationally-representative sample of 2,515 respondents completed the online survey between February 14 and 28, 2020.

The questions test public opinions about raising the federal gas tax rate, replacing the federal gas tax with a new mileage fee, and imposing a mileage fee just on commercial travel. In addition to asking directly about support for these tax options, the survey collected data on respondents' views on the quality of their local transportation system, their priorities for federal transportation spending, their knowledge about gas taxes, their views on privacy and equity matters related to mileage fees, travel behavior, and standard sociodemographic variables. This large set of variables is used to identify personal characteristics and opinions correlated with support for the tax options.

Key findings include that large majorities supported transportation improvements across modes, only $3 \%$ of respondents knew that the federal gas tax rate had not been raised in more than 20 years, three-quarters of respondents supported increasing the federal gas tax by 10 cents-per-gallon if the revenue would be dedicated to maintenance, roughly half of respondents supported some form of mileage fee, whether that was assessed on all travel or just on commercial travel, and three-quarters of respondents would prefer to pay a mileage fee in small installments instead of in one annual payment.

\section{Key Words}

Transportation taxes, transportation fees, public opinion, gasoline tax, mileage fees, highway user taxation, user charges

19. Security Classif. (of this report) Unclassified
18. Distribution Statement

No restrictions. This document is available to the public through The National Technical Information Service, Springfield, VA 22161

20. Security Classif. (of this page) Unclassified
21. No. of Pages

70
22. Price 


\title{
Copyright $\odot 2020$ \\ by Mineta Transportation Institute \\ All rights reserved
}

\section{DOI: \\ 10.31979/mti.2020.2007}

\author{
Mineta Transportation Institute \\ College of Business \\ San José State University \\ San José, CA 95192-0219 \\ Tel: (408) 924-7560 \\ Fax: (408) 924-7565 \\ Email: mineta-institute@sjsu.edu
}

transweb.sjsu.edu 


\section{ACKNOWLEDGMENTS}

The authors thank the following people for their important contributions to this project:

- Student Research Assistant Cameron Simons, for data analysis

- Student Research Assistant Chenyi Luo, for producing the figures

- The authors thank Editing Press for editorial services, as well as MTI staff, including Executive Director Karen Philbrick, Ph.D.; Research Support Assistant Joseph Mercado; and Executive Administrative Assistant Jill Carter. 


\section{TABLE OF CONTENTS}

I. Introduction 1

II. Survey Design and Administration 3

Questionnaire Design 3

Survey Administration 4

Survey Respondents $\quad 6$

III. Findings Related to Respondents' Views on Transportation System Needs 8

Perceived Quality of the Local Transportation System 8

Priorities for the National Transportation System 9

IV. Findings Related to Federal Gas Taxes 14

Knowledge About Federal and State Gas Tax Rates 14

Support for Raising the Federal Gas Tax Rate 19

Trends in Support Over Time (2010 - 2020) 26

Support for Spending Some Gas Tax Revenues on Public Transit 28

V. Findings About Mileage Fees $\quad 32$

Opinions About Privacy and Fairness $\quad 32$

Support for Replacing the Gas Tax with a Mileage Fee 44

Preferred Way to Pay for Mileage Fees 48

Support for a Business Road-Use Fee $\quad 51$

VI. Conclusions $\quad 56$

Public Priorities for Improving the Transportation System 56

Gas Taxes $\quad 56$

$\begin{array}{ll}\text { Mileage Fees } & 57\end{array}$

$\begin{array}{ll}\text { Variations by Personal Characteristics } & 57\end{array}$

Appendix A: Survey Questionnaire and Topline Results $\quad 58$

$\begin{array}{ll}\text { Endnotes } & 65\end{array}$

$\begin{array}{lr}\text { Bibliography } & 67\end{array}$

$\begin{array}{ll}\text { About the Authors } & \mathbf{7 0}\end{array}$ 


\section{LIST OF FIGURES}

1. Assessment of the Quality of Transportation Infrastructure and Services in "Your Community," 2019 - 2020

2. Assessment of the Importance of Transportation-Related Goals for the U.S., 2019 - 2020

3. Priority Placed on Different Options for Spending Federal Gas Tax Revenue, 2019 - 2020

4. Options Selected as One of the Top Three Priorities for Spending Federal Gas Tax Revenue

5. Percent of Respondents Who Supported the Gas Tax Options

20

6. Trends in Support for the Gas Tax Options, $2010-2020$

7. Support for the Mileage Fee Options, $2019-2020$ 


\section{LIST OF TABLES}

1. Quotas Used for Sampling $\quad 5$

2. Comparison of Survey Respondents to the U.S. Population $\quad 7$

3. Respondents' Belief About When the U.S. Congress Last Raised the Federal Gas Tax

4. Accuracy of Respondents' Belief About When Their State Gas Tax Was Last Raised

5. Respondents' Belief About When the Federal Gas Tax Was Last Raised, by Sociodemographic Characteristics

6. Respondents' Belief About When the Federal Gas Tax Was Last Raised, by Political Characteristics

7. Respondents' Belief About When the Federal Gas Tax Was Last Raised, by Travel Behavior

8. Respondents' Belief About When the Federal Gas Tax Was Last Raised, by Census Region and Community Type

9. Percent of Respondents Who Supported the Gas Tax Options, by Sociodemographic Characteristics

10. Percent of Respondents Who Supported the Gas Tax Options, by Political Characteristics

11. Support for the Gas Tax Options, by Travel Behavior

12. Support for the Gas Tax Options, by Opinion on When Federal Gas Tax Was Last Raised and Monthly Fuel Expenditures

13. Support for the Gas Tax Options, by Census Region and Community Type

14. Support for the Gas Tax Options, by Opinion on Spending Some Gas Tax Revenue for Transit

15. Trends in Support for the Gas Tax Options, $2010-2020$

16. Support for Spending Some Gas Tax Revenue for Transit, by Sociodemographic Characteristics

17. Support for Spending Some Gas Tax Revenue for Transit, by Political Characteristics 
18. Support for Spending Some Gas Tax Revenue for Transit, by Travel Behavior

19. Support for Spending Some Gas Tax Revenue for Transit, by Census Region and Community Type

20. Percent of Respondents Not Concerned About the Privacy Implications of a Mileage Fee, by Sociodemographic Characteristics

21. Percent of Respondents Not Concerned About the Privacy Implications of a Mileage Fee, by Political Characteristics

22. Percent of Respondents Not Concerned About the Privacy Implications of a Mileage Fee, by Travel Behavior

23. Percent of Respondents Not Concerned About the Privacy Implications of a Mileage Fee, by Census Region and Community Type

24. Respondents' Opinion About Whether Mileage Fees are More or Less Fair than Gas Taxes, by Sociodemographic Characteristics

25. Respondents' Opinion About Whether Mileage Fees are More or Less Fair than Gas Taxes, by Political Characteristics

26. Respondents' Opinion About Whether Mileage Fees are More or Less Fair than Gas Taxes, by Travel Behavior

27. Respondents' Opinion About Whether Mileage Fees are More or Less Fair than Gas Taxes, by Census Region and Community Type

28. Preferred Mileage Fee Rate for Electric Vehicles, as Compared to the Rate for Gas and Diesel Vehicles, by Sociodemographics

29. Preferred Mileage Fee Rate for Electric Vehicles, as Compared to the Rate for Gas and Diesel Vehicles, by Political Characteristics

30. Preferred Mileage Fee Rate for Electric Vehicles, as Compared to the Rate for Gas and Diesel Vehicles, by Travel Behavior

31. Preferred Mileage Fee Rate for Electric Vehicles, as Compared to the Rate for Gas and Diesel Vehicles, by Census Region and Community Type

32. Preferred Mileage Fee Rate for Electric Vehicles, as Compared to the Rate for Gas and Diesel Vehicles, by Opinions About Mileage Fees

33. Support for the Mileage Fee Options, by Sociodemographic Characteristics

34. Support for the Mileage Fee Options, by Political Characteristics 
35. Support for the Mileage Fee Options, by Travel Behavior

36. Support for the Mileage Fee Options, by Census Region and Community Type 47

37. Support for the Mileage Fee Options, by Opinions About Privacy and Fairness 48

38. Preferred Frequency for Paying a Mileage Fee, by Sociodemographic Characteristics

39. Preferred Frequency for Paying a Mileage Fee, by Political Characteristics

40. Preferred Frequency for Paying a Mileage Fee, by Travel Behavior

41. Preferred Frequency for Paying a Mileage Fee, by Census Region and Community Type

42. Preferred Frequency for Paying a Mileage Fee, by Opinions About Mileage Fees

43. Support for a Business Road-Use Fee, by Sociodemographic Characteristics

44. Support for a Business Road-Use Fee, by Political Characteristics

45. Support for a Business Road-Use Fee, by Travel Behavior

46. Support for a Business Road-Use Fee, by Census Region and Community Type

47. Support for a Business Road-Use Fee, by Opinions About Mileage Fees 


\section{INTRODUCTION}

Over the past several decades, the transportation revenues available from state and federal gas taxes have fallen significantly in terms of inflation-adjusted dollars per mile traveled. At the same time, the transportation system requires critical - and expensive - system upgrades. Among other needs, a large portion of the national highway system requires major rehabilitation, and there is growing desire at all levels of government to substantially upgrade and expand infrastructure to support public transit, walking, bicycling, and micromobility modes such as electric kick-scooters.

This dilemma of growing needs and shrinking revenues can be resolved in only two ways: either the nation must dramatically lower its goals for system preservation and enhancement, or new revenues must be raised. If the latter is to happen, legislators must be convinced that increasing taxes or fees is politically feasible. One portion of the political calculus that legislators make when deciding whether or not to raise new revenues is, of course, the likelihood of public support for - or opposition to - raising different kinds of taxes.

This report contributes to the understanding of public sentiment about increasing transportation taxes by presenting results from the eleventh year of an annual survey investigating public opinion about a variety of federal-level transportation tax options. The survey data was collected in February 2020, just prior to the dramatic travel restrictions imposed nationally in response to the COVID-19 pandemic.

The specific taxes tested were six variants of a federal gas tax increase, two variants of a new mileage fee on all travel that would replace the federal gas tax, and three variants of a mileage fee for commercial travel that would be levied in addition to the federal gas tax. In addition to asking directly about support for these tax options, the survey collected data on respondents' views on the quality of their local transportation system, their priorities for federal transportation spending, their knowledge about gas taxes, their views on privacy and equity matters related to mileage fees, travel behavior, and standard sociodemographic variables. All this information was used to assess support levels for the tax options among different population subgroups.

The survey questionnaire described the various tax proposals in general terms only, so the study results cannot be assumed to reflect support for any actual proposal put forward. Nevertheless, the results show likely patterns of support and, more important, the public's relative preferences among different transportation tax options.

The report compares the results of the eleven surveys in the series to establish how public views may have changed since 2010. To permit reliable trend analysis, the surveys used identical question language each year to describe most of the tax options. ${ }^{1}$ However, starting last year, the survey was administered using an online panel, unlike previous years that gathered data through a random-digit-dialing phone survey. Comparisons of results from before and after the change in survey mode should be interpreted with care, since changes in survey mode can affect responses. 
The remaining chapters of the report are organized as follows. Chapter 2 describes the survey methodology and presents an overview of the questionnaire and details of the implementation procedure. Discussion of the survey findings follows in Chapter 3 , Chapter 4 , and Chapter 5. Chapter 6 summarizes the key findings and suggests policy implications and future research needs. 


\section{SURVEY DESIGN AND ADMINISTRATION}

The online survey was completed by 2,515 U.S. adults, who were recruited by Qualtrics through an online panel sample. This chapter describes the questionnaire design, survey sampling and administration, and characteristics of the respondents.

\section{QUESTIONNAIRE DESIGN}

The survey questionnaire was designed to test public support for variants on taxes that could be used to raise federal transportation revenues: an increase in the federal gas tax rate, a new national mileage fee to replace the federal gas tax, and a new mileage fee assessed only on commercial travel. The exact wording used for all questions can be found in Appendix A, which reproduces the survey questionnaire.

Because gas taxes and mileage fees are revenue options likely to receive considerable policy scrutiny in coming years, the survey tested support for different versions of each tax. Overall, 11 different federal tax options were tested: 6 variants of a gas tax increase, 2 variants of a new mileage fee on all travel to replace the federal gas tax, and 3 variants of a mileage fee for commercial travel that would be levied in addition to the gas tax. To permit trend analysis, most of the gas tax variants were described with identical language to that used in earlier years of the survey series. The two mileage fee variants were described with the same wording as last year.

To make these hypothetical taxes easier for respondents to understand, the survey gave specific amounts for the gas tax increases and mileage fee on all travel. The amounts were selected to be simple numbers within the range of mainstream current policy discussion.

Gas-tax increases: All variants of a federal gas tax increase involved raising the existing $18 \phi$-per-gallon tax ${ }^{2}$ to $28 \phi$ per gallon, but each included a different set of information for respondents to consider. The six variations were:

- A "base-case" $10 \phi$ increase in the gas tax, with respondents given no information other than the rate and that proceeds would be spent "for transportation."

- A $10 \phi$ increase in the gas tax, with the revenues to be spent only for projects to reduce local air pollution caused by the transportation system.

- A $10 \phi$ increase in the gas tax, with the revenues to be spent only on projects to reduce the transportation system's contribution to global warming.

- A $10 \phi$ increase in the gas tax, with the revenues to be spent only on projects to maintain streets, roads, and highways.

- A $10 \phi$ increase in the gas tax, with the revenues to be spent only on projects to reduce accidents and improve safety.

- A $10 \phi$ increase in the gas tax, with the revenues to be spent only on projects to reduce traffic congestion. (This option was added to the survey in 2019.) 
New mileage fees to replace the gas tax: Two variants of a mileage fee on all travel were presented. Both involved replacing the federal gasoline tax with a new fee that charges drivers for each mile driven and relies on electronic meters to track mileage. ${ }^{3}$ Respondents were also told that someone driving 10,000 miles a year would pay $\$ 100$. The two variants, which differed only in the rate structure, were:

- "Flat-rate" variant: a one-cent-per-mile fee, with every car taxed at the same rate.

- "Green" variant: a mileage fee for which the average rate would be one cent per mile, but vehicles that pollute less would be charged less and vehicles that pollute more would be charged more.

A "Business Road-Use Fee": New to this year's survey was a question asking respondents about a hypothetical "Business Road-Use Fee" that would be assessed on miles that commercial vehicles drive on the job. Those vehicles would continue to pay the current gas tax as well. Respondents were asked if they would support such a tax on different types of commercial travel: delivery and freight trucks, taxis, and ridehailing vehicles.

The survey also asked several questions to test support for specific features of a hypothetical new mileage fee on all travel: whether respondents thought all-electric vehicles should pay a higher or lower rate than gas and diesel vehicles, whether they would be bothered having their mileage tracked, whether they see a mileage fee as more or less fair than a gas tax, and how often they would prefer to pay a new mileage fee (each time they buy gas or charge a vehicle, once a month, or annually).

To provide context for understanding respondents' views on gas and mileage taxes, the questionnaire also asked respondents to rate the quality of transportation infrastructure and services in their community, their goals for improving transportation across the U.S., their priorities for different ways the federal government could spend gas tax revenues, their estimate of how recently gas tax rate has been raised nationally and in their state, simple travel behavior questions, and standard socio-demographic questions.

\section{SURVEY ADMINISTRATION}

The survey was administered online, using a survey platform and panel of respondents managed by Qualtrics. Online surveys are increasingly popular, in part due to their low cost, speed at which they can be administered, convenience for respondents, and ability to include question design options that are difficult or impossible to implement via telephone or mail. ${ }^{4}$ A 2019 analysis from the Pew Research Center found that $90 \%$ of Americans are online,$^{5}$ which suggests that online surveys are currently a reasonable method to reach a representative sample of US adults, despite evidence that some population subgroups are often underrepresented in online surveys. Groups less well represented include people who are older, low-income, have less formal education, live in rural communities, and do not have high-speed internet access at home. ${ }^{6}$ 
Through 2018, the surveys in the series gathered data through random-digit-dial telephone surveys. In 2019, we changed the survey mode to take advantage of the benefits of online surveys. Compared to a phone survey, online surveys are much less expensive and avoid some challenges specific to telephone surveys, such as their intrusive nature and increased use of call screening. ${ }^{7}$

Survey mode can impact question responses, so readers are cautioned that when trends are discussed in this report's findings, the change in survey mode could account for some of the difference between responses in 2018 and 2019. A study by the authors of this report, for example, found higher support levels for some of the same tax options described here were higher when responses were collected from the online panel "SurveyMonkey Audience" than when responses were collected with a random-digit-dial phone survey. ${ }^{8}$ However, research suggests that questions about abstract policy matters (like those in this survey) are less affected by survey mode than questions about potentially embarrassing personal topics where respondents may feel pressured to give socially acceptable answers. Researcher have also found that respondents to online polls are also less likely to answer rating questions with the most positive answers than are phone survey respondents. ${ }^{9}$

\section{Sampling Approach}

Quota sampling was used in order a sample that closely represents the US adult population. The authors requested a nationally-representative sample, as defined by American Community Survey (ACS) data on gender, race and ethnicity, employment status, annual household income, and age. Table 1 shows the ACS values used to build the quotas.

Table 1. Quotas Used for Sampling

\begin{tabular}{llc}
\hline Characteristic & & U.S. adult population ${ }^{\mathrm{a}} \%$ \%) \\
\hline Gender & Male & 49 \\
& Female & 51 \\
\hline Race/ethnicity & White only & 52 \\
& Hispanic/Latino origin/descent & 18 \\
& Black/African-American only & 12 \\
& Asian/Asian-American only & 12 \\
& Other, including multiracial & 6 \\
\hline Income (annual household) & $\$ 0-\$ 50,000$ & 42 \\
& $\$ 50,001-\$ 99,999$ & 30 \\
& $\$ 100,000-\$ 149,999$ & 15 \\
& $\$ 150,000+$ & 13 \\
\hline Age (years) & $18-34$ & 30 \\
& $35-54$ & 33 \\
\hline
\end{tabular}

a All data are for adults 18 years and older, with the exception of household income, which is for all U.S. households. Source: U.S. Census Bureau's 2014-2018 American Community Survey 5-Year Public Use Microdata Samples, downloaded from data.census.gov. 
Interviews were conducted from February 14 to February 28, 2020. The median time to complete each survey was 10 minutes, and the mean time was 13 minutes. A total of 2,515 adults responded with usable data. We did not calculate response or frequency rates because the Qualtrics sampling method does not track how many people received the survey invitation.

\section{SURVEY RESPONDENTS}

The 2,515 adult survey respondents with usable data were generally representative of the U.S. population in terms of Census region and sociodemographic characteristics (Table 3 ). For the survey findings and analysis presented in this report, we lightly weighted the data using a raking method to match the Census Bureau's 2018 American Community Survey five-year estimates with respect to gender, race, Hispanic ethnicity, education level, household income, and age. ${ }^{10}$ 
Table 2. Comparison of Survey Respondents to the U.S. Population

\begin{tabular}{|c|c|c|c|}
\hline \multicolumn{2}{|l|}{ Characteristic } & Sample (\%) & U.S. adults ${ }^{a}(\%)$ \\
\hline \multirow[t]{4}{*}{ Census region ${ }^{b}$} & Northeast & 22 & 18 \\
\hline & Midwest & 18 & 21 \\
\hline & South & 39 & 38 \\
\hline & West & 22 & 24 \\
\hline \multirow[t]{3}{*}{ Gender } & Male & 49 & 49 \\
\hline & Female & 51 & 51 \\
\hline & Other & $<1$ & -- \\
\hline \multicolumn{2}{|c|}{ Of Hispanic/Latino origin/descent } & 18 & 16 \\
\hline \multirow[t]{4}{*}{ Race } & White only & 63 & 74 \\
\hline & Black/African-American only & 13 & 12 \\
\hline & Asian/Asian-American only & 12 & 6 \\
\hline & Other, including multiracial & 12 & 8 \\
\hline \multirow[t]{5}{*}{ Education } & Less than high school graduate & 3 & 11 \\
\hline & High school graduate & 20 & 36 \\
\hline & Some college & 33 & 24 \\
\hline & College graduate & 29 & 18 \\
\hline & Graduate degree & 16 & 11 \\
\hline \multirow[t]{3}{*}{ Employment status } & Working for pay & 55 & 61 \\
\hline & Unemployed, but looking for work & 12 & 4 \\
\hline & Not working by choice (retired, etc.) & 33 & 35 \\
\hline \multirow[t]{7}{*}{ Income (annual household) } & $\$ 0-\$ 24,999$ & 20 & 18 \\
\hline & $\$ 25,000-\$ 49,999$ & 22 & 20 \\
\hline & $\$ 50,000-\$ 74,999$ & 18 & 17 \\
\hline & $\$ 75,000-\$ 99,999$ & 12 & 12 \\
\hline & $\$ 100,000-\$ 149,999$ & 15 & 15 \\
\hline & $\$ 150,000-\$ 199,999$ & 7 & 7 \\
\hline & $\$ 200,000+$ & 6 & 11 \\
\hline \multirow[t]{8}{*}{ Age (years) } & $18-24$ & 10 & 12 \\
\hline & $25-34$ & 20 & 18 \\
\hline & $35-44$ & 21 & 16 \\
\hline & $45-54$ & 13 & 17 \\
\hline & $55-64$ & 18 & 17 \\
\hline & $65-74$ & 16 & 11 \\
\hline & $75-84$ & 3 & 6 \\
\hline & $85+$ & $<1$ & 2 \\
\hline
\end{tabular}

a All data are for adults 18 years and older, with the exception of household income, which is for all U.S. households. Source: Steven Ruggles, Sarah Flood, Ronald Goeken, Josiah Grover, Erin Meyer, Jose Pacas and Matthew Sobek. IPUMS USA: Version 10.0 [dataset]. Minneapolis, MN: IPUMS, 2020. https://doi.org/10.18128/D010.V10.0.

b Census regions are defined at U.S. Census Bureau, "Census Regions and Divisions of the United States with State FIPS Codes," http://www2.census.gov/geo/docs/maps-data/maps/reg_div.txt.

Note: Some percentages do not sum to $100 \%$ due to rounding. 


\section{FINDINGS RELATED TO RESPONDENTS' VIEWS ON TRANSPORTATION SYSTEM NEEDS}

This chapter presents key findings from a set of questions asking respondents their views on the quality of the current transportation system and priorities for improving it. (Appendix A presents the exact questionnaire language and complete top-line results.)

\section{PERCEIVED QUALITY OF THE LOCAL TRANSPORTATION SYSTEM}

Figure 1 shows how respondents assessed the quality of transportation infrastructure and services in their own community. The grey bars to the left indicate the percent of respondents who assessed each type of transportation infrastructure or service negatively (as somewhat or very bad), while the blue bars to the left show the percentage of respondents who assessed each item positively (as somewhat or very good). The figure also shows the percent of respondents who responded "not sure/doesn't apply."

The majority of respondents rated the transportation system positively, though with some reservations. For every item, more than half of respondents rated it as "somewhat" or "very" good. However, more people selected "somewhat" rather than "very" good.

Comparing responses across the four items, interstates, highways, and freeways were rated positively by the largest percent of respondents (75\%). The other three items were rated positively by somewhat smaller majorities: $63 \%$ for local streets and roads, $58 \%$ for bicycle and pedestrian facilities, and $55 \%$ for public transit. Considerably more people responded "don't know" about bicycle and pedestrian facilities and public transit than for the two types of road infrastructure.

Responses in 2020 followed roughly the same pattern as in 2019 , though slightly more people had positive ratings in 2020 for all but bicycle and pedestrian facilities.

A separate question asked respondents if they were concerned about traffic congestion in their community. Thirty-four percent were very concerned, $42 \%$ were somewhat concerned, and only $24 \%$ were not at all concerned. 
Findings Related to Respondents' Views on Transportation System Needs

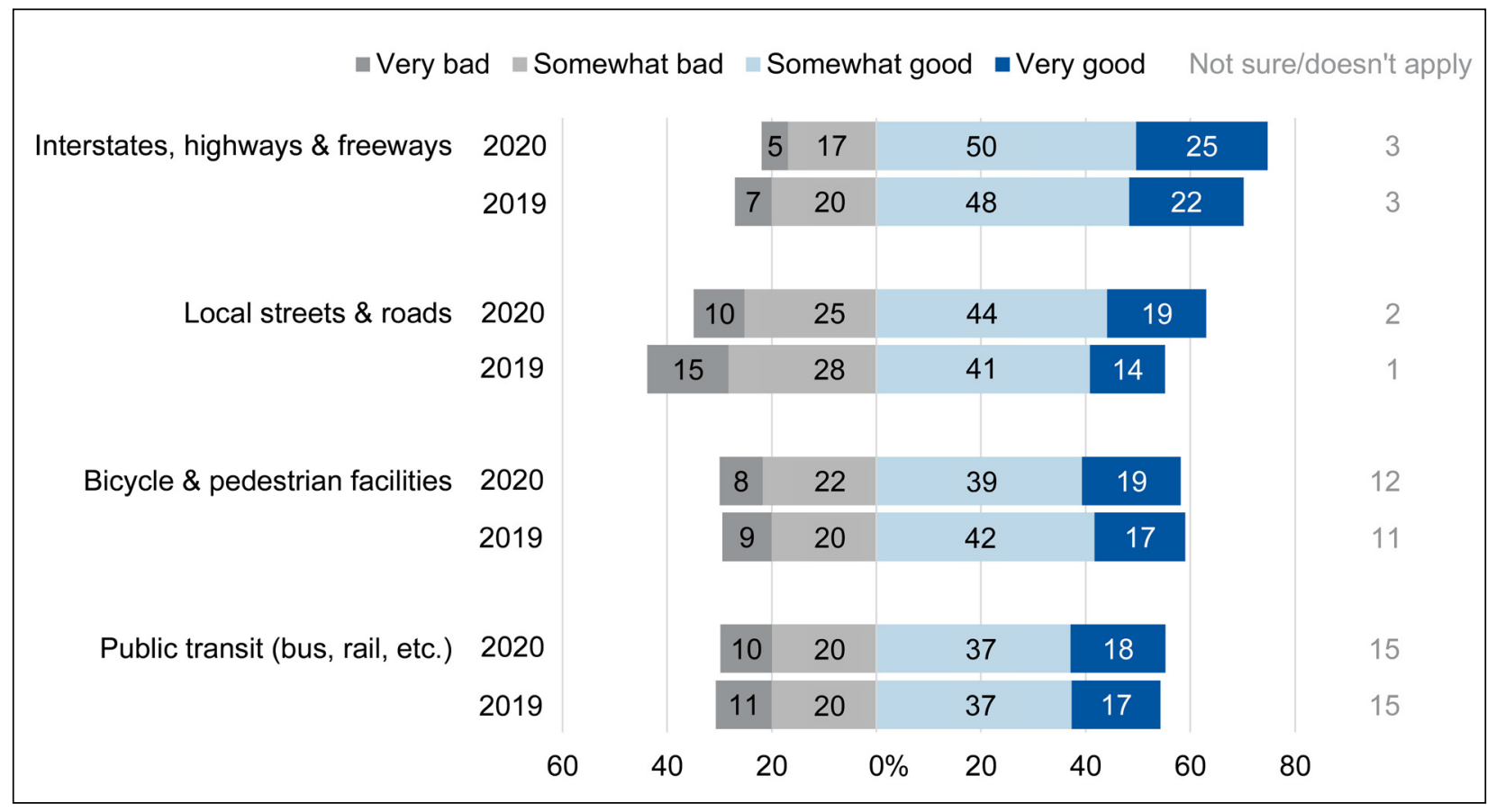

Figure 1. Assessment of the Quality of Transportation Infrastructure and Services in "Your Community," 2019 - 2020

\section{PRIORITIES FOR THE NATIONAL TRANSPORTATION SYSTEM}

The next set of survey questions asked respondents about their priorities for improvements to the transportation system, asking first about national goals and then about preferred ways to spend federal gas tax revenues.

Figure 2 shows the importance that respondents placed on each of seven goals for improving the national transportation system, comparing 2020 and 2019 data for the six goals tested both years. The blue bars to the right indicate the percentages rating each goal as "somewhat" or "very" important, and the grey bars to the left represent the proportion rating the goal as "not important." Across both years, virtually all respondents (89\% or more) rated each of the seven goals as "somewhat" or "very" important, with more selecting "very" than "somewhat" important. In 2020 , for example, $75 \%$ of respondents said it was "very" important to maintain and improve roads, streets, highways, and bridges, and $58 \%$ said it was "very" important to maintain and improve public transit. The two most popular goals in both years were to improve maintenance on roads, streets, highways, and bridges and to improve safety. 


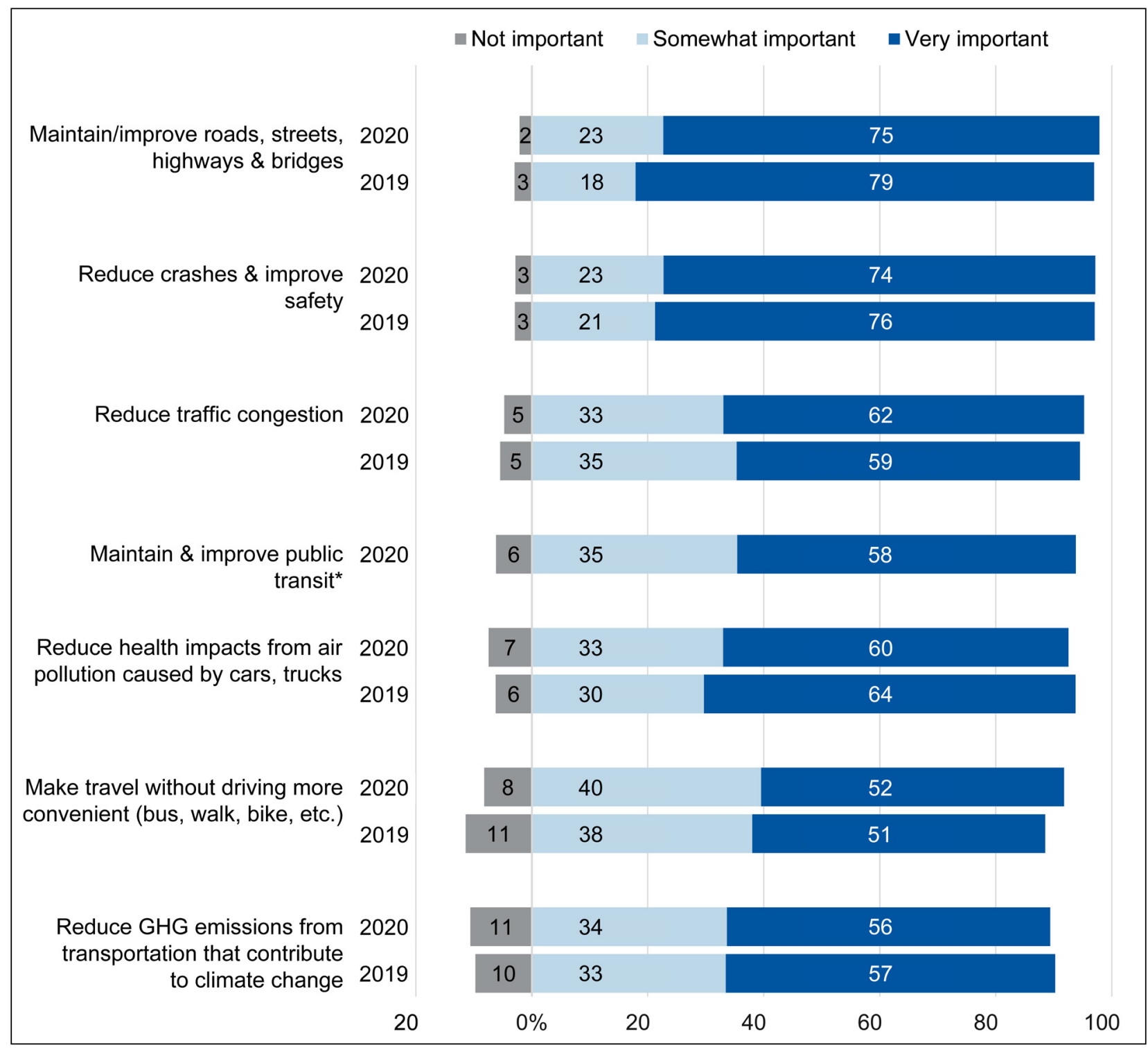

Figure 2. Assessment of the Importance of Transportation-Related Goals for the U.S., $2019-2020$

*Option not included in the 2019 survey.

The questionnaire then explained that the federal government collects a tax on gasoline and asked respondents to indicate how much of a priority they would place on each of 13 different categories of spending. Figure 3 presents the results from both 2020 and 2019. There was no major variation from year to year. In both years, the great majority of respondents indicated that all these options are of medium to high priority. Also, in neither year did any spending option have more than $13 \%$ rate it as "not at all" a priority.

Looking at respondents' relative priorities, maintenance was a very high priority. The options to maintain highways and freeways and to maintain local streets and roads were both a priority for the largest number of respondents (94\% and $93 \%$, respectively, in 2020). Maintenance of public transit was important to almost as many (87\% in 2020). 
Large majorities also supported both road and public-transit related options, from building and widening local streets, roads, and highways, to adding more frequent transit service and offering discounted fares to low-income riders. The two options with the lowest support both related to encouraging use of electric vehicles, but even here clear majorities supported the options as at least a "medium" priority.

Finally, a follow-up question asked respondents to choose their three highest priorities from the list of 13 possible spending categories. As Figure 4 shows, there was little consensus; no single option was selected by a majority of respondents. However, mirroring respondents' rating for each spending option, the most commonly selected top priority was maintenance: maintaining local streets and roads (37\%) and maintaining highways and freeways (33\%). The most popular public transit-related option, "discounted public transit fares for low-income people," was selected by $23 \%$ of respondents. As for active transportation, building/improving sidewalks was a top priority for $22 \%$, though only $11 \%$ selected "build and improve bike lanes and paths" as a priority. Measures to support EV use were a priority for comparatively few respondents, with $14 \%$ selecting "financial incentives to purchase EVs" and 8\% selecting "more charging stations for EVs." 


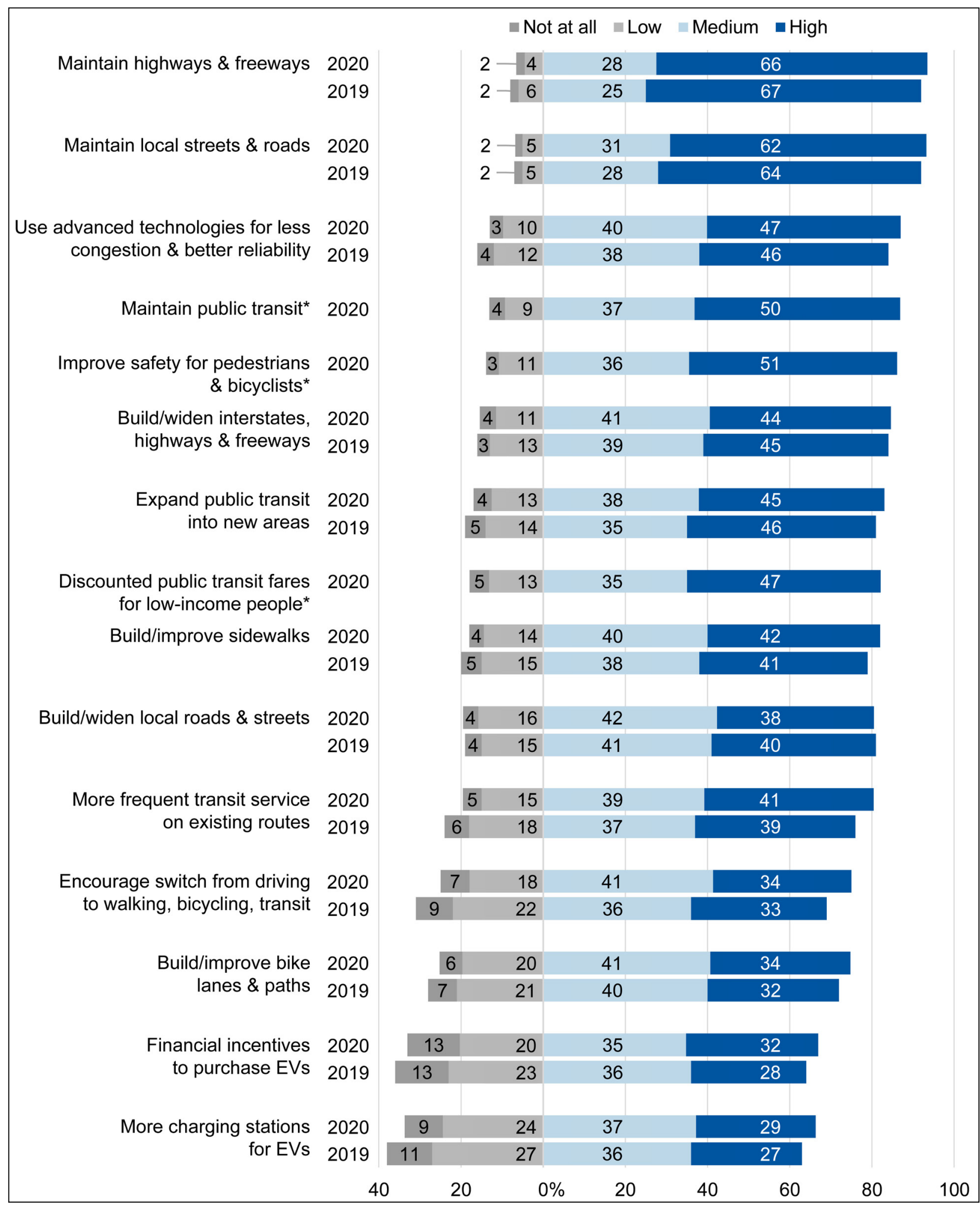

Figure 3. Priority Placed on Different Options for Spending Federal Gas Tax Revenue, 2019 - 2020

*Option not included in the 2019 survey. 
Findings Related to Respondents' Views on Transportation System Needs

Maintain local streets \& roads

Maintain highways \& freeways

Use advanced technologies for less congestion \& better reliability

Discounted public transit fares for low-income people

Build/improve sidewalks

Expand public transit service into new areas

Build/widen interstates, highways \& freeways

Encourage switch from driving to walking, bicycling, transit

More frequent transit service on existing routes

Improve safety for pedestrians \& bicyclists

Maintain public transit

Build/widen local roads \& streets

Financial incentives to purchase EVs

Build/improve bike lanes \& paths

More charging stations for EVs
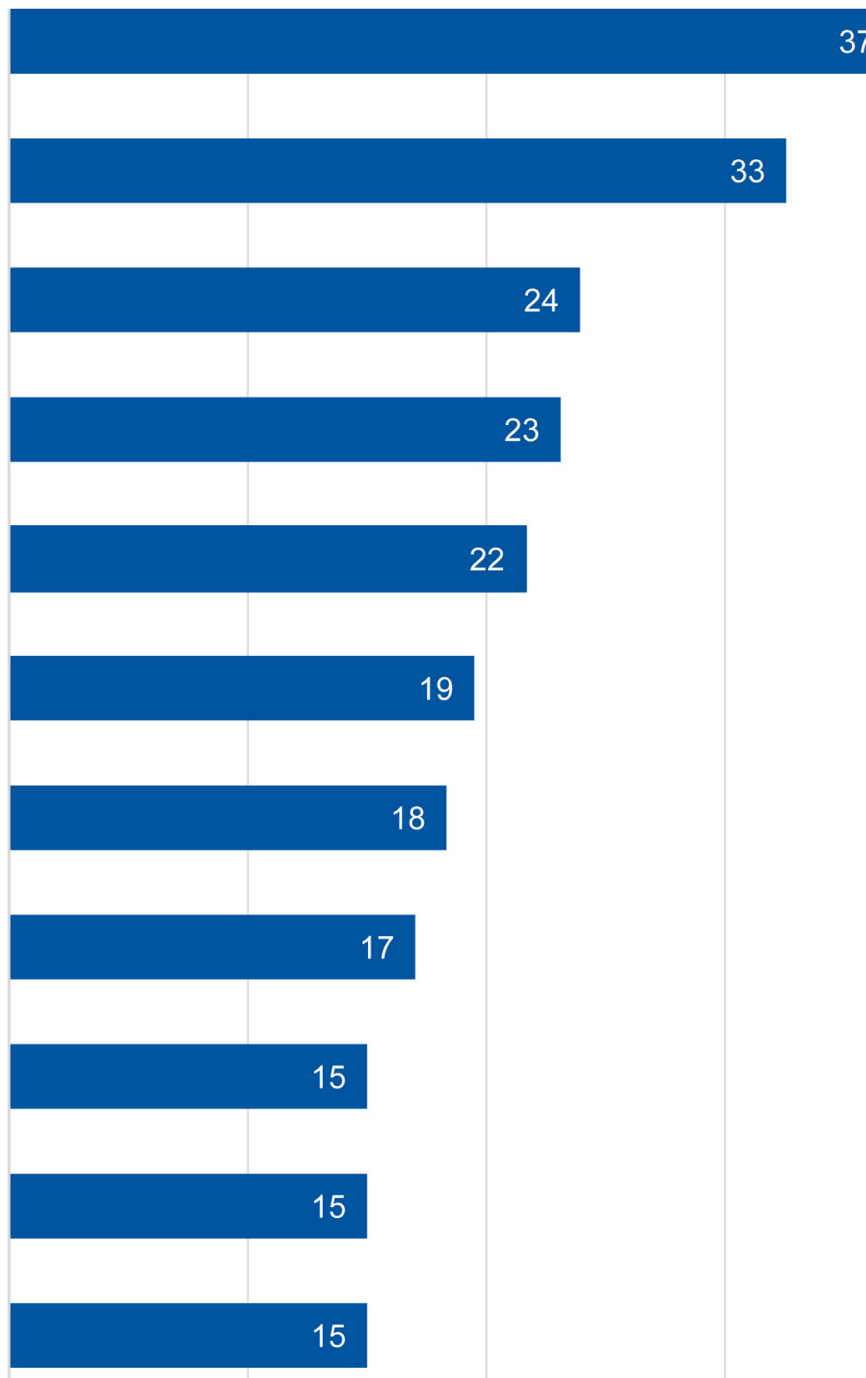

Figure 4. Options Selected as One of the Top Three Priorities for Spending Federal Gas Tax Revenue 


\section{FINDINGS RELATED TO FEDERAL GAS TAXES}

This chapter presents findings on questions related to knowledge and opinions about the federal gas tax. Topics covered include how much respondents think they pay in federal gas taxes and support for different variants on raising the federal gas tax rate. (Appendix A presents the exact questionnaire language and topline results.)

The chapter also examines how support levels for the different tax options varies by subgroups within the population. For example, we compare support levels for women versus men, and for urban vs. rural residents. The statistical test of two proportions was used to check whether differences among subgroups (e.g., men versus women) are statistically significant at the $95 \%$ and $99 \%$ confidence levels. In the tables presenting these results, the first subgroup listed for each population characteristic (e.g., age or race) is the base case against which the other subgroups are compared.

\section{KNOWLEDGE ABOUT FEDERAL AND STATE GAS TAX RATES}

Considerable anecdotal evidence suggests most Americans are unaware of how much they pay in fuel taxes, and surveys such as the 2019 report in this series have documented that most people overestimate the federal gas tax rate. ${ }^{11}$ This year, we decided to gather evidence on a related aspect of the public's knowledge about the gas tax: their best guess about how recently the gas tax rate had been raised by both the federal government and the respondent's home state. To make the questions easier to answer, respondents were asked to select a time range rather than specify the exact number of years. The options offered were up to 3 years ago, 4 to 10 years ago, 11 to 15 years ago, 16 to 20 years ago, and more than 20 years ago.

The survey found that virtually none of the respondents-only $3 \%$ - knew that the federal gas tax has not been raised in more than 20 years (Table 3). More than half simply said that they didn't know (55\%), and a third believed that the tax had been raised within the past 10 years $(34 \%)$.

Table 3. Respondents' Belief About When the U.S. Congress Last Raised the Federal Gas Tax

\begin{tabular}{lc}
\hline & $\%$ \\
\hline 1 to 3 years ago & 20 \\
4 to 10 years ago & 14 \\
11 to 15 years ago & 6 \\
16 to 20 years ago & 2 \\
More than 20 years ago (correct answer) & 3 \\
Don't know & 55 \\
\hline
\end{tabular}

Somewhat more respondents had an accurate sense of when the gas tax was last raised in their home state (Table 4). A quarter (25\%) chose the correct time category. However, $14 \%$ thought that the rate had been raised longer ago than it had, and $11 \%$ thought it had been raised more recently than it had. Finally, half (49\%) said they didn't know when their state gas tax rate had been raised. 
Table 4. Accuracy of Respondents' Belief About When Their State Gas Tax Was Last Raised

\begin{tabular}{|c|c|c|c|c|c|}
\hline \multirow{2}{*}{$\begin{array}{l}\text { How long ago respondents } \\
\text { believe their state gas tax } \\
\text { was last raised }\end{array}$} & \multicolumn{5}{|c|}{ Years since the state gas tax was last raised } \\
\hline & $\begin{array}{c}\text { Within the last } \\
3 \text { years }\end{array}$ & 4 to 10 years & 11 to 15 years & 16 to 20 years & $\begin{array}{c}\text { More than } \\
20 \text { years }\end{array}$ \\
\hline 1 to 3 years & 23 & 3 & $<1$ & $<1$ & 3 \\
\hline 4 to 10 years & 9 & 3 & $<1$ & $<1$ & 3 \\
\hline 11 to 15 years & 3 & 1 & $<1$ & $<1$ & $<1$ \\
\hline 16 to 20 years & 1 & $<1$ & 0 & $<1$ & 1 \\
\hline More than 20 years & 1 & $<1$ & 0 & $0 \%$ & $<1$ \\
\hline Don't know & 32 & 6 & 1 & $<1$ & 10 \\
\hline
\end{tabular}

Note: Cells in green indicate that the respondent correctly identified when their state gas tax was last raised. Cells in blue indicate that the respondent believed it has been longer than it actually has since the state gas tax was last raised. Cells in yellow indicate that the respondents believe that the gas tax has been raised more recently than it actually has.

For knowledge about the federal gas tax, we also explored whether particular subgroups were more likely to correctly know that the rate had not been raised in over 20 years. Tables 5 through 8 present this analysis, highlighting the larger variations among subgroups. The tables identify variations between the reference subgroup in each category and other subgroups where the difference is statistically significant and at least ten percentage points. Readers should note that the differences highlighted below are not necessarily the only important differences that exist. Rather, the variations discussed are those that (1) fell within the cutoff point selected and (2) were statistically significant according to the particular statistical tests used. Choosing a different cutoff point would highlight a somewhat different set of variations. It is also important to keep in mind that "statistical significance" is not an automatic indicator of scientific or policy importance, as discussed in a 2016 statement from the American Statistical Association. ${ }^{12}$

The analysis of subgroups found statistically significant differences of ten or more percentage points by race, employment status, age, political affiliation, having paid a toll in the previous 30 days, and community type. 
Table 5. Respondents' Belief About When the Federal Gas Tax Was Last Raised, by Sociodemographic Characteristics

\begin{tabular}{|c|c|c|c|c|}
\hline Subgroup & $\begin{array}{c}1 \text { to } 10 \text { years } \\
\text { ago }(\%)\end{array}$ & $\begin{array}{c}11 \text { to } 20 \text { years } \\
\text { ago }(\%)\end{array}$ & $\begin{array}{l}\text { More than } 20 \\
\text { years ago }(\%)\end{array}$ & $\begin{array}{c}\text { Don't know } \\
(\%)\end{array}$ \\
\hline All respondents & 34 & 8 & 3 & 55 \\
\hline \multicolumn{5}{|l|}{ Gender } \\
\hline Male & 34 & 9 & 4 & 53 \\
\hline Female & 33 & $6^{*}$ & $2^{*}$ & $58^{*}$ \\
\hline \multicolumn{5}{|l|}{ Race } \\
\hline White & 30 & 7 & 4 & 59 \\
\hline Black/African-American only & $47^{* *}$ & $12^{* *}$ & $1^{* *}$ & $40^{* *}$ \\
\hline Asian/Asian-American only & 31 & 4 & 1 & 64 \\
\hline Other & $42^{* *}$ & 7 & $1^{*}$ & $49^{* *}$ \\
\hline \multicolumn{5}{|l|}{ Of Latino/Hispanic descent } \\
\hline Yes & 40 & 7 & 2 & 50 \\
\hline No & $32^{* *}$ & 8 & 3 & $57^{* *}$ \\
\hline \multicolumn{5}{|l|}{ Education } \\
\hline High school graduate or less & 39 & 7 & 3 & 52 \\
\hline More than high school & $31^{* *}$ & 8 & 4 & $58^{\star *}$ \\
\hline \multicolumn{5}{|l|}{ Employment status } \\
\hline Working for pay & 37 & 9 & 3 & 51 \\
\hline Unemployed, but looking for work & $46^{* *}$ & 7 & 2 & 46 \\
\hline Not working by choice (retired, etc.) & $25^{\star *}$ & $6^{*}$ & 4 & $65^{\star *}$ \\
\hline \multicolumn{5}{|l|}{ Income (annual household) } \\
\hline $0-\$ 50,000$ & 38 & 7 & 2 & 53 \\
\hline$\$ 50,001-\$ 100,000$ & $30^{* *}$ & $10^{* *}$ & 4 & 56 \\
\hline$\$ 100,001+$ & $30^{* *}$ & 7 & $4^{* *}$ & $58^{*}$ \\
\hline \multicolumn{5}{|l|}{ Age (years) } \\
\hline $18-24$ & 46 & 14 & 4 & 37 \\
\hline $25-54$ & $35^{* *}$ & $7^{* *}$ & 2 & $56^{* *}$ \\
\hline $55+$ & $28^{* *}$ & $6^{* *}$ & 4 & $62^{* *}$ \\
\hline
\end{tabular}

* Statistically significant at $p<0.05 .{ }^{* *}$ Statistically significant at $p<0.01$.

Note: The test of two proportions was used to check if there is a statistically significant difference between subgroups. The first subgroup in each category is the reference case against which the proportion of respondents in other subgroups is compared. Values in blue cells are at least ten percentage points different from the reference case. 
Table 6. Respondents' Belief About When the Federal Gas Tax Was Last Raised, by Political Characteristics

\begin{tabular}{|c|c|c|c|c|}
\hline Subgroup & $\begin{array}{c}1 \text { to } 10 \text { years } \\
\text { ago }(\%)\end{array}$ & $\begin{array}{c}11 \text { to } 20 \text { years } \\
\text { ago }(\%)\end{array}$ & $\begin{array}{l}\text { More than } 20 \\
\text { years ago }(\%)\end{array}$ & $\begin{array}{c}\text { Don't know } \\
(\%)\end{array}$ \\
\hline All respondents & 34 & 8 & 3 & 55 \\
\hline \multicolumn{5}{|l|}{ Registered voter } \\
\hline Yes & 34 & 8 & 3 & 55 \\
\hline No & 32 & 8 & 3 & 58 \\
\hline \multicolumn{5}{|l|}{ Likely voter ${ }^{a}$} \\
\hline Yes & 34 & 7 & 4 & 55 \\
\hline No & 33 & 8 & $2^{*}$ & 57 \\
\hline \multicolumn{5}{|l|}{ Political affiliation } \\
\hline Republican (and lean Republican) $)^{\mathrm{b}}$ & 35 & 7 & 4 & 53 \\
\hline Democrat (and lean Democrat) ${ }^{b}$ & 35 & 9 & $2^{\star *}$ & 54 \\
\hline Independent, no party affiliation & $27^{* *}$ & 5 & 4 & $64^{* *}$ \\
\hline Some other party ${ }^{c}$ & 23 & 2 & 2 & $73^{* *}$ \\
\hline
\end{tabular}

** Statistically significant at $p<0.01$.

a Likely voters are those respondents who said that they are registered voters and that they vote "all of the time" or "most of the time."

b Included registered members of the political party and those respondents who stated that they were independent or a member of another political party but chose to indicate which party they "leaned" towards.

c Registered member of any other party.

Note: The test of two proportions was used to check if there is a statistically significant difference between subgroups.

The first subgroup in each category is the reference case against which the proportion of respondents in other

subgroups is compared. Values in blue cells are at least ten percentage points different from the reference case. 
Table 7. Respondents' Belief About When the Federal Gas Tax Was Last Raised, by Travel Behavior

\begin{tabular}{|c|c|c|c|c|}
\hline \multirow[b]{2}{*}{ Subgroup } & \multicolumn{4}{|c|}{ Federal } \\
\hline & $\begin{array}{c}1 \text { to } 10 \text { years } \\
\text { ago }(\%)\end{array}$ & $\begin{array}{c}11 \text { to } 20 \text { years } \\
\text { ago }(\%)\end{array}$ & $\begin{array}{c}\text { More than } 20 \text { years } \\
\text { ago }(\%)\end{array}$ & $\begin{array}{c}\text { Don't know } \\
(\%)\end{array}$ \\
\hline All respondents & 34 & 8 & 3 & 55 \\
\hline \multicolumn{5}{|c|}{ Annual miles driven } \\
\hline $1-7,500$ & 37 & 7 & 3 & 53 \\
\hline $7,501-12,500$ & $30^{* *}$ & $11^{* *}$ & 4 & 56 \\
\hline $12,501+$ & $31^{*}$ & 9 & 4 & 56 \\
\hline Don't drive & $31^{*}$ & 5 & 2 & $61^{* *}$ \\
\hline \multicolumn{5}{|l|}{ Miles per gallona } \\
\hline$\leq 19$ & 37 & 8 & 3 & 52 \\
\hline $20-30$ & $30^{* *}$ & 7 & 4 & $59^{*}$ \\
\hline $31+$ & 41 & 10 & 1 & 47 \\
\hline \multicolumn{5}{|c|}{ Transit used in last 30 days } \\
\hline Yes & 39 & 8 & 4 & 49 \\
\hline No & $32^{* *}$ & 8 & 3 & $57^{* *}$ \\
\hline \multicolumn{5}{|c|}{ Paid a toll in last 30 days } \\
\hline Yes & 39 & 10 & 4 & 46 \\
\hline No & $32^{* *}$ & $7^{*}$ & 3 & $57^{* *}$ \\
\hline
\end{tabular}

* Statistically significant at $p<0.05$. ${ }^{* *}$ Statistically significant at $p<0.01$.

a Categories drawn from EPA's "SmartWay" vehicle rating system (U.S. Environmental Protection Agency, "SmartWay Vehicle Thresholds MY 2015” (January 2014), https://nepis.epa.gov/Exe/ZyPURL.cgi?Dockey=P100HP2R.TXT.

Note: The test of two proportions was used to check if there is a statistically significant difference between subgroups. The first subgroup in each category is the reference case against which the proportion of respondents in other subgroups is compared. Values in blue cells are at least ten percentage points different from the reference case. 
Table 8. Respondents' Belief About When the Federal Gas Tax Was Last Raised, by Census Region and Community Type

\begin{tabular}{|c|c|c|c|c|}
\hline Subgroup & $\begin{array}{c}1 \text { to } 10 \text { years ago } \\
(\%)\end{array}$ & $\begin{array}{c}11 \text { to } 20 \text { years } \\
\text { ago }(\%)\end{array}$ & $\begin{array}{l}\text { More than } 20 \\
\text { years ago }(\%)\end{array}$ & $\begin{array}{c}\text { Don't know } \\
(\%)\end{array}$ \\
\hline All respondents & 34 & 8 & 3 & 55 \\
\hline \multicolumn{5}{|l|}{ Census region } \\
\hline Northeast & 32 & 9 & 5 & 54 \\
\hline Midwest & $39^{*}$ & 7 & 3 & 51 \\
\hline South & 33 & 8 & $3^{*}$ & 57 \\
\hline West & 33 & 7 & $2^{*}$ & 58 \\
\hline \multicolumn{5}{|c|}{ Community type (self-reported) } \\
\hline Urban & 40 & 8 & 4 & 48 \\
\hline Suburban & $30^{* *}$ & 8 & 2 & $60^{* *}$ \\
\hline Small town & 37 & 6 & 5 & 52 \\
\hline Rural & $31^{* *}$ & 6 & 4 & $60^{* *}$ \\
\hline
\end{tabular}

${ }^{*}$ Statistically significant at $p<0.05 .{ }^{* *}$ Statistically significant at $p<0.01$.

Note: The test of two proportions was used to check if there is a statistically significant difference between subgroups. The first subgroup in each category is the reference case against which the proportion of respondents in other subgroups is compared. Values in blue cells are at least ten percentage points different from the reference case.

\section{SUPPORT FOR RAISING THE FEDERAL GAS TAX RATE}

The survey results show that a majority of Americans would support higher taxes for transportation - under certain conditions (Figure 5). Less than half of respondents (44\%) supported the base-case $10 \phi$-per-gallon gas tax increase, for which respondents were told only that the tax revenues would be spent for transportation purposes. However, the five variants on that idea of a $10 \phi$-per-gallon gas tax increase received from $56 \%$ to $75 \%$ support. The very highest level of support among all the tax options tested was for a gas tax increase of $10 \phi$ per gallon, with the proceeds dedicated to street, road, and highway maintenance. Seventy-five percent of respondents supported this option, an increase of 31 percentage points over support for the base-case gas tax increase. The next most popular options were a gas tax increase with funds devoted to reducing accidents and improving safety (73\% support) or one with funds devoted to reducing congestion $(71 \%)$. The two options that linked a gas tax increase to environment objectives had strong but somewhat lower support levels: $61 \%$ for the variant related to reducing global warming emissions and $56 \%$ support for the variant related to reducing local air pollution caused by transportation. 
Maintain streets, roads \& highways

Reduce accidents \& improve safety

Reduce congestion

Reduce transportation's contribution to global warming

Reduce local air pollution caused by transportation

Base case

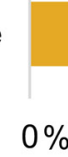

$0 \%$

Figure 5. Percent of Respondents Who Supported ${ }^{a}$ the Gas Tax Options

a "Support" is the sum of those who said that they "strongly" or "somewhat" support the tax option.

As in the preceding chapter, we looked for variations in support among respondents with different characteristics. The results of this analysis are shown in Tables 9 through 14, where cells highlighted in blue indicate subgroups that are ten percentage points or more different from the reference case. Overall, there were relative few subgroups that were notably more supportive. Among the variations that met the ten-point threshold, very few were related to the maintenance and safety options, while there were somewhat more for the base-case and two environmentally-focused tax options. Subgroups that stood out as notably more supportive of the taxes across the board were respondents aged $18-24$, who leaned towards the Democratic party, drove the least (1 to 7,500 miles annually), thought the federal gas tax had been raised within the last ten years (as opposed to 11 to 20 years ago), spent the least on fuel ( $\$ 1$ to $\$ 50$ monthly), and lived in urban areas.

We also looked at whether support for the gas tax increases is correlated with support for spending gas tax revenue on public transit, a topic discussed at more length in the next section. The pattern is strikingly clear, with people who supported the principle of spending gas tax revenue on transit being more likely to support all six of the gas tax variants (Table 14). The magnitude of the differences is also among the largest to show up in the subgroup analysis. There is a 12-percentage point difference even for the gas tax variant for maintenance, which is the most universally popular among the gas tax options. For the other variants, the percentage point difference rose much higher, including a 33 percentage-point difference in support for the base-case gas tax increase. 
Table 9. Percent of Respondents Who Supported the Gas Tax Options, by Sociodemographic Characteristics (2020)

\begin{tabular}{|c|c|c|c|c|c|c|}
\hline \multirow[b]{2}{*}{ Subgroup } & \multirow[b]{2}{*}{$\begin{array}{c}\text { Base-case } \\
10 \phi \\
\text { increase }\end{array}$} & \multicolumn{5}{|c|}{ Revenue to ... } \\
\hline & & $\begin{array}{c}\text { Reduce } \\
\text { local air } \\
\text { pollution } \\
(\%)\end{array}$ & $\begin{array}{c}\text { Reduce } \\
\text { global } \\
\text { warming } \\
(\%) \\
\end{array}$ & $\begin{array}{c}\text { Maintain } \\
\text { streets/ } \\
\text { highways } \\
(\%)\end{array}$ & $\begin{array}{l}\text { Improve } \\
\text { safety (\%) }\end{array}$ & $\begin{array}{c}\text { Reduce } \\
\text { congestion } \\
(\%)\end{array}$ \\
\hline All respondents & 44 & 56 & 61 & 75 & 73 & 71 \\
\hline \multicolumn{7}{|l|}{ Gender } \\
\hline Male & 42 & 56 & 60 & 73 & 70 & 69 \\
\hline Female & 46 & 56 & 62 & 76 & $77^{* *}$ & $74^{* *}$ \\
\hline \multicolumn{7}{|l|}{ Race } \\
\hline White & 40 & 54 & 60 & 74 & 72 & 70 \\
\hline Black/African-American only & $58^{* *}$ & 60 & 64 & 73 & 76 & $75^{*}$ \\
\hline Asian/Asian-American only & 47 & $66^{*}$ & 68 & 80 & 80 & $82^{* *}$ \\
\hline Other & 46 & 60 & 64 & 78 & 73 & 74 \\
\hline \multicolumn{7}{|l|}{ Of Latino/Hispanic descent } \\
\hline Yes & 52 & 62 & 67 & 76 & 78 & 75 \\
\hline No & $42^{* *}$ & $55^{* *}$ & $60^{* *}$ & 74 & $72^{* *}$ & 71 \\
\hline \multicolumn{7}{|l|}{ Education } \\
\hline High school graduate or less & 48 & 55 & 59 & 73 & 73 & 70 \\
\hline More than high school & $42^{* *}$ & 57 & 63 & 75 & 73 & 72 \\
\hline \multicolumn{7}{|l|}{ Employment status } \\
\hline Working for pay & 48 & 56 & 62 & 72 & 72 & 70 \\
\hline Unemployed, but looking for work & 51 & $64^{* *}$ & $69^{*}$ & 75 & 75 & 73 \\
\hline Not working by choice (retired, etc.) & $36^{* *}$ & 54 & $58^{*}$ & $77^{\star *}$ & 74 & 72 \\
\hline \multicolumn{7}{|l|}{ Income (annual household) } \\
\hline $0-\$ 50,000$ & 44 & 60 & 64 & 77 & 76 & 73 \\
\hline$\$ 50,001-\$ 100,000$ & 41 & $50^{* *}$ & $58^{*}$ & 75 & $70^{* *}$ & 71 \\
\hline$\$ 100,001+$ & 47 & $54^{* *}$ & 61 & $70^{\star *}$ & $70^{* *}$ & 69 \\
\hline \multicolumn{7}{|l|}{ Age (years) } \\
\hline $18-24$ & 56 & 67 & 75 & 76 & 76 & 71 \\
\hline $25-54$ & $49^{*}$ & $54^{* *}$ & $59^{* *}$ & 72 & 72 & 70 \\
\hline $55+$ & $34^{* *}$ & $55^{\star *}$ & $60^{* *}$ & 78 & 73 & 73 \\
\hline
\end{tabular}

* Statistically significant at $p<0.05 .{ }^{* *}$ Statistically significant at $p<0.01$.

a Sum of those who "strongly" or "somewhat" supported the option.

Note: The test of two proportions was used to check if there is a statistically significant difference between subgroups. The first subgroup in each category is the reference case against which the proportion of respondents in other subgroups is compared. Values in blue cells are at least ten percentage points different from the reference case. 


\section{Table 10. Percent of Respondents Who Supported ${ }^{a}$ the Gas Tax Options, by Political Characteristics}

\begin{tabular}{|c|c|c|c|c|c|c|}
\hline \multirow[b]{2}{*}{ Subgroup } & \multirow[b]{2}{*}{$\begin{array}{c}\text { Base-case } \\
10 \phi \\
\text { increase } \\
(\%) \\
\end{array}$} & \multicolumn{5}{|c|}{ Revenue to ... } \\
\hline & & $\begin{array}{l}\text { Reduce } \\
\text { local air } \\
\text { pollution } \\
\quad(\%)\end{array}$ & $\begin{array}{l}\text { Reduce } \\
\text { global } \\
\text { warming } \\
(\%)\end{array}$ & $\begin{array}{c}\text { Maintain } \\
\text { streets/ } \\
\text { highways } \\
(\%)\end{array}$ & $\begin{array}{c}\text { Improve } \\
\text { safety } \\
(\%)\end{array}$ & $\begin{array}{c}\text { Reduce } \\
\text { congestion } \\
(\%)\end{array}$ \\
\hline All respondents & 44 & 56 & 61 & 75 & 73 & 71 \\
\hline \multicolumn{7}{|l|}{ Registered voter } \\
\hline Yes & 43 & 55 & 61 & 75 & 73 & 72 \\
\hline No & 48 & $62^{* *}$ & 62 & 72 & 74 & 71 \\
\hline \multicolumn{7}{|l|}{ Likely voter ${ }^{b}$} \\
\hline Yes & 43 & 55 & 61 & 75 & 72 & 71 \\
\hline No & $47^{*}$ & $59^{*}$ & 63 & 74 & $76^{*}$ & 71 \\
\hline \multicolumn{7}{|l|}{ Political affiliation } \\
\hline Republican (and lean Republican) ${ }^{c}$ & 36 & 45 & 48 & 71 & 67 & 65 \\
\hline Democrat (and lean Democrat) ${ }^{c}$ & $49^{* *}$ & $65^{\star *}$ & $73^{* *}$ & $78^{* *}$ & $77^{* *}$ & $76^{* *}$ \\
\hline Independent, no party affiliation & $48^{* *}$ & $59^{* *}$ & $60^{* *}$ & 72 & 71 & 70 \\
\hline Some other party ${ }^{d}$ & 40 & 49 & $63^{*}$ & 84 & $83^{*}$ & $81^{*}$ \\
\hline
\end{tabular}

* Statistically significant at $p<0.05 .{ }^{* *}$ Statistically significant at $p<0.01$.

a Sum of those who said that they "strongly" or "somewhat" supported the option.

b Likely voters are those respondents who said that they are registered voters and that they vote "all of the time" or "most of the time."

c Included registered members of the political party and those respondents who stated that they were independent or a member of another political party but chose to indicate which party they "leaned" towards.

d Registered member of any other party.

Note: The test of two proportions was used to check if there is a statistically significant difference between support levels among subgroups. The first subgroup listed in each category is the reference case for the test; the proportion of respondents who supported the individual policies in each of the other subgroups within that category is compared to the reference case. 
Table 11. Support ${ }^{a}$ for the Gas Tax Options, by Travel Behavior

\begin{tabular}{|c|c|c|c|c|c|c|}
\hline \multirow[b]{2}{*}{ Subgroup } & \multirow[b]{2}{*}{$\begin{array}{c}\text { Base-case } \\
10 \phi \\
\text { increase } \\
(\%)\end{array}$} & \multicolumn{5}{|c|}{ Revenue to ... } \\
\hline & & $\begin{array}{l}\text { Reduce } \\
\text { local air } \\
\text { pollution } \\
(\%)\end{array}$ & $\begin{array}{c}\text { Reduce } \\
\text { global } \\
\text { warming } \\
(\%)\end{array}$ & $\begin{array}{c}\text { Maintain } \\
\text { streets/ } \\
\text { highways } \\
(\%)\end{array}$ & $\begin{array}{l}\text { Improve } \\
\text { safety } \\
(\%)\end{array}$ & $\begin{array}{c}\text { Reduce } \\
\text { congestion } \\
(\%)\end{array}$ \\
\hline All respondents & 44 & 56 & 61 & 75 & 73 & 71 \\
\hline \multicolumn{7}{|c|}{ Annual miles driven } \\
\hline $1-7,500$ & 43 & 58 & 65 & 77 & 76 & 75 \\
\hline $7,501-12,500$ & 38 & $52^{*}$ & $58^{* *}$ & $72^{*}$ & $68^{* *}$ & $68^{* *}$ \\
\hline $12,501+$ & 42 & $47^{* *}$ & $53^{* *}$ & $71^{*}$ & $64^{* *}$ & $64^{* *}$ \\
\hline Don't drive & $57^{* *}$ & $65^{*}$ & 64 & 76 & 79 & 71 \\
\hline \multicolumn{7}{|l|}{ Miles per gallon ${ }^{b}$} \\
\hline$\leq 19$ & 39 & 49 & 58 & 71 & 72 & 72 \\
\hline $20-30$ & 38 & $56^{*}$ & 62 & $76^{*}$ & 73 & 71 \\
\hline $31+$ & $50^{* *}$ & $57^{*}$ & 61 & $76^{*}$ & 70 & 73 \\
\hline \multicolumn{7}{|c|}{ Transit used in last 30 days } \\
\hline Yes & 57 & 63 & 66 & 76 & 76 & 75 \\
\hline No & $40^{* *}$ & $54^{* *}$ & $60^{*}$ & 74 & $72^{*}$ & $70^{*}$ \\
\hline \multicolumn{7}{|c|}{ Paid a toll in last 30 days } \\
\hline Yes & 49 & 56 & 62 & 75 & 72 & 71 \\
\hline No & $39^{* *}$ & 54 & 61 & 74 & 72 & 71 \\
\hline
\end{tabular}

* Statistically significant at $p<0.05 .{ }^{* *}$ Statistically significant at $p<0.01$.

a Sum of those who "strongly" or "somewhat" supported the option.

b Categories drawn from EPA's "SmartWay" vehicle rating system (U.S. Environmental Protection Agency, "SmartWay Vehicle Thresholds MY 2015” (January 2014), https://nepis.epa.gov/Exe/ZyPURL.cgi?Dockey=P100HP2R.TXT.

Note: The test of two proportions was used to check if there is a statistically significant difference between subgroups. The first subgroup in each category is the reference case against which the proportion of respondents in other subgroups is compared. Values in blue cells are at least ten percentage points different from the reference case. 


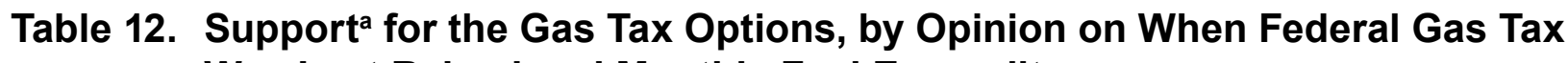
Was Last Raised and Monthly Fuel Expenditures

\begin{tabular}{|c|c|c|c|c|c|c|}
\hline \multirow[b]{2}{*}{ Respondents' estimates } & \multirow[b]{2}{*}{$\begin{array}{c}\text { Base- } \\
\text { case 10 } \phi \\
\text { increase } \\
(\%)\end{array}$} & \multicolumn{5}{|c|}{ Revenue to ... } \\
\hline & & $\begin{array}{c}\text { Reduce } \\
\text { local air } \\
\text { pollution } \\
(\%)\end{array}$ & $\begin{array}{c}\text { Reduce } \\
\text { global } \\
\text { warming } \\
(\%)\end{array}$ & $\begin{array}{c}\text { Maintain } \\
\text { streets/ } \\
\text { highways } \\
(\%)\end{array}$ & $\begin{array}{c}\text { Improve } \\
\text { safety (\%) }\end{array}$ & $\begin{array}{c}\text { Reduce } \\
\text { congestion } \\
(\%)\end{array}$ \\
\hline All respondents & 44 & 56 & 61 & 75 & 73 & 71 \\
\hline \multicolumn{7}{|c|}{ Estimates on when federal gas tax was last raised } \\
\hline 1 to 10 years ago & 51 & 61 & 67 & 78 & 77 & 76 \\
\hline 11 to 20 years ago & $60^{*}$ & $51^{* *}$ & 60 & $60^{* *}$ & $56^{\star *}$ & $59^{* *}$ \\
\hline More than 20 years ago & 41 & 64 & 63 & 85 & 72 & 76 \\
\hline Don't know & $37^{* *}$ & $54^{* *}$ & $58^{* *}$ & $74^{*}$ & $73^{*}$ & $70^{* \star}$ \\
\hline \multicolumn{7}{|c|}{ Estimated monthly fuel expenditures } \\
\hline$\$ 1-\$ 50$ & 41 & 56 & 60 & 74 & 73 & 74 \\
\hline$\$ 51-\$ 100$ & 40 & 57 & 63 & 77 & 73 & 72 \\
\hline$\$ 101-\$ 150$ & 45 & 53 & 59 & 72 & 70 & 71 \\
\hline$\$ 151-\$ 200$ & 37 & $42^{* *}$ & 63 & 76 & 73 & 68 \\
\hline$\$ 201+$ & 47 & 48 & 51 & $62^{*}$ & $58^{\star *}$ & $55^{\star \star}$ \\
\hline
\end{tabular}

* Statistically significant at $p<0.05$. ** Statistically significant at $p<0.01$.

a Sum of those who said that they "strongly" or "somewhat" supported the option.

Note: The test of two proportions was used to check if there is a statistically significant difference between subgroups. The first subgroup in each category is the reference case against which the proportion of respondents in other subgroups is compared. Values in blue cells are at least ten percentage points different from the reference case. 


\section{Table 13. Support ${ }^{\mathrm{a}}$ for the Gas Tax Options, by Census Region and Community Type}

\begin{tabular}{|c|c|c|c|c|c|c|}
\hline \multirow[b]{2}{*}{ Subgroup } & \multirow[b]{2}{*}{$\begin{array}{c}\text { Base-case } \\
10 \phi \\
\text { increase } \\
(\%)\end{array}$} & \multicolumn{5}{|c|}{ Revenue to ... } \\
\hline & & $\begin{array}{c}\text { Reduce } \\
\text { local air } \\
\text { pollution } \\
(\%)\end{array}$ & $\begin{array}{l}\text { Reduce } \\
\text { global } \\
\text { warming } \\
(\%)\end{array}$ & $\begin{array}{c}\text { Maintain } \\
\text { streets/ } \\
\text { highways } \\
(\%)\end{array}$ & $\begin{array}{c}\text { Improve } \\
\text { safety } \\
(\%)\end{array}$ & $\begin{array}{c}\text { Reduce } \\
\text { congestion } \\
(\%)\end{array}$ \\
\hline All respondents & 44 & 56 & 61 & 75 & 73 & 71 \\
\hline \multicolumn{7}{|l|}{ Census region } \\
\hline Northeast & 46 & 57 & 61 & 74 & 73 & 71 \\
\hline Midwest & 41 & 56 & 63 & 78 & 75 & 70 \\
\hline South & 45 & 55 & 59 & 73 & 71 & 70 \\
\hline West & 42 & 58 & 66 & 74 & 75 & $76^{*}$ \\
\hline \multicolumn{7}{|c|}{ Community type (self-reported) } \\
\hline Urban & 55 & 62 & 67 & 77 & 77 & 78 \\
\hline Suburban & $42^{* *}$ & $55^{* *}$ & $60^{* *}$ & $72^{* *}$ & $71^{* *}$ & $71^{* *}$ \\
\hline Small town & $33^{* *}$ & $55^{*}$ & $58^{* *}$ & 77 & 74 & $64^{* *}$ \\
\hline Rural & $36^{\star *}$ & 50 ** & $57^{* *}$ & 76 & $67^{* *}$ & $67^{* *}$ \\
\hline
\end{tabular}

* Statistically significant at $p<0.05$. ** Statistically significant at $p<0.01$.

a Sum of those who "strongly" or "somewhat" supported the option.

Note: The test of two proportions was used to check if there is a statistically significant difference between support levels among subgroups. The first subgroup listed in each category is the reference case for the test; the proportion of respondents who support the individual policies in each of the other subgroups within that category is compared to the reference case.

Table 14. Support ${ }^{a}$ for the Gas Tax Options, by Opinion on Spending Some Gas Tax Revenue for Transit

\begin{tabular}{|c|c|c|c|c|c|c|}
\hline \multirow[b]{2}{*}{ Opinion } & \multirow[b]{2}{*}{$\begin{array}{c}\text { Base-case } \\
10 \phi \\
\text { increase } \\
(\%) \\
\end{array}$} & \multicolumn{5}{|c|}{ Revenue to ... } \\
\hline & & $\begin{array}{l}\text { Reduce } \\
\text { local air } \\
\text { pollution } \\
(\%)\end{array}$ & $\begin{array}{c}\text { Reduce } \\
\text { global } \\
\text { warming } \\
(\%)\end{array}$ & $\begin{array}{c}\text { Maintain } \\
\text { streets/ } \\
\text { highways } \\
(\%)\end{array}$ & $\begin{array}{c}\text { Improve } \\
\text { safety } \\
(\%)\end{array}$ & $\begin{array}{c}\text { Reduce } \\
\text { congestion } \\
(\%)\end{array}$ \\
\hline All respondents & 44 & 56 & 61 & 75 & 73 & 71 \\
\hline Support spending gas tax on transit & 54 & 63 & 69 & 78 & 78 & 75 \\
\hline Oppose spending gas tax on transit & $20^{* *}$ & $38^{* *}$ & $43^{* *}$ & $67^{* *}$ & $61^{* *}$ & $63^{* *}$ \\
\hline
\end{tabular}

** Statistically significant at $p<0.01$.

a Sum of those who said that they "strongly" or "somewhat" supported the option.

Note: The test of two proportions was used to check if there is a statistically significant difference between subgroups. The first subgroup in each category is the reference case against which the proportion of respondents in other subgroups is compared. Values in blue cells are at least ten percentage points different from the reference case. 


\section{TRENDS IN SUPPORT OVER TIME (2010 - 2020)}

The surveys have asked about support for many of the same gas tax variants each year, to allow an assessment of trends. Figure 6 and Table 15 both show support for these five tax options over time. In the past year, support for the tax options has varied little. Looking back to 2011, in every case where the question has been asked annually, support has risen over the years, with an increase of more than 10 percentge points for all but the air pollution variant.

When interpreting the trends, readers should note that the survey mode changed in 2019; earlier surveys collected data from an RDD phone survey, whereas this year's respondents came from an online panel survey. Evidence suggests that changes in survey mode can influence both who responds and how people respond to surveys. For example, Nixon and Agrawal ran a survey experiment with the same gas tax questions presented here, using both an RDD phone survey and an online panel from SurveryMonkey. That study found systematically higher support for the taxes among the online respondents as compared to the phone survey respondents, even though both samples were weighted to match the U.S. population across age, gender, ethnicity, race, and income. ${ }^{13}$

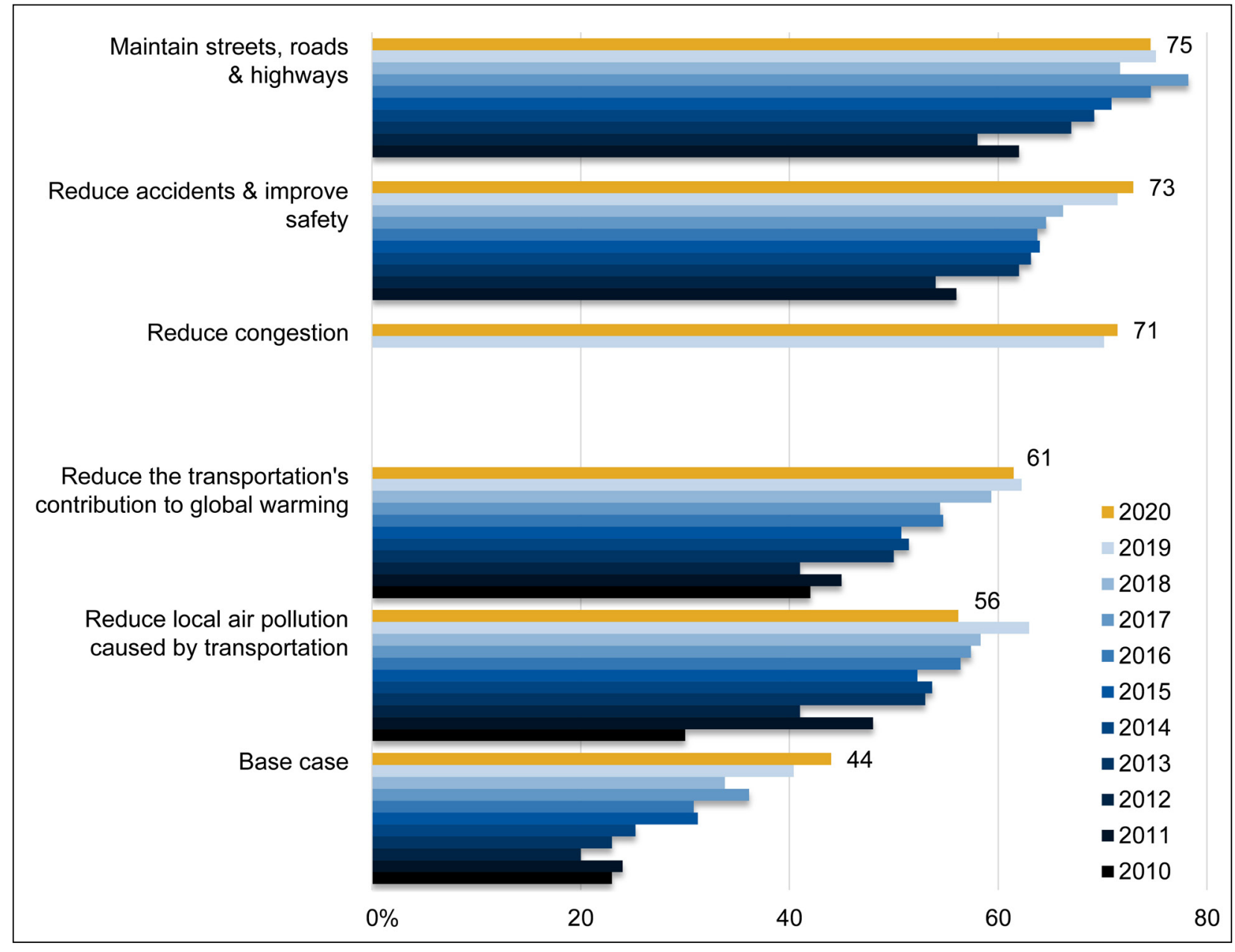

Figure 6. Trends in Support ${ }^{\mathrm{a}}$ for the Gas Tax Options, $2010-2020$

a "Support" is the sum of those who "strongly" or "somewhat" supported the tax option.

Note: In 2019, the survey mode changed from a random-digit-dial phone survey to an online panel survey. Comparisons of results from before and after should be interpreted with care, since changes in survey mode can effect responses. 
Table 15. Trends in Support ${ }^{\text {a }}$ for the Gas Tax Options, $2010-2020$

\begin{tabular}{|c|c|c|c|c|c|c|c|c|c|c|c|c|c|}
\hline \multirow[b]{2}{*}{ Tax option } & \multirow[b]{2}{*}{$\begin{array}{c}2010 \\
(\%) \\
\end{array}$} & \multirow[b]{2}{*}{$\begin{array}{c}2011 \\
(\%)\end{array}$} & \multirow[b]{2}{*}{$\begin{array}{c}2012 \\
(\%)\end{array}$} & \multirow[b]{2}{*}{$\begin{array}{c}2013 \\
(\%)\end{array}$} & \multirow[b]{2}{*}{$\begin{array}{c}2014 \\
(\%)\end{array}$} & \multirow[b]{2}{*}{$\begin{array}{c}2015 \\
(\%)\end{array}$} & \multirow[b]{2}{*}{$\begin{array}{c}2016 \\
(\%)\end{array}$} & \multirow[b]{2}{*}{$\begin{array}{c}2017 \\
(\%)\end{array}$} & \multirow[b]{2}{*}{$\begin{array}{c}2018 \\
(\%)\end{array}$} & \multirow[b]{2}{*}{$\begin{array}{c}2019^{b} \\
(\%)\end{array}$} & \multirow[b]{2}{*}{$\begin{array}{c}2020 \\
(\%)\end{array}$} & \multicolumn{2}{|c|}{ Differences } \\
\hline & & & & & & & & & & & & $\begin{array}{c}2020-2011 \\
(\%)\end{array}$ & $\begin{array}{c}2020-2019 \\
(\%)\end{array}$ \\
\hline Base case & 23 & 24 & 20 & 23 & 25 & 31 & 31 & 36 & 34 & 40 & 44 & $20^{* *}$ & $4^{* *}$ \\
\hline $\begin{array}{l}\text { Revenues spent to reduce local air } \\
\text { pollution }\end{array}$ & 30 & 48 & 41 & 53 & 54 & 52 & 56 & 57 & 58 & 63 & 56 & $8^{* *}$ & $-7^{* *}$ \\
\hline Revenues spent to reduce global warming & 42 & 45 & 41 & 50 & 51 & 51 & 55 & 54 & 59 & 62 & 61 & $16^{* *}$ & -1 \\
\hline $\begin{array}{l}\text { Revenues spent to maintain streets, roads, } \\
\text { and highways }\end{array}$ & $--^{c}$ & 62 & 58 & 67 & 69 & 71 & 75 & 78 & 72 & 75 & 75 & $13^{* *}$ & -1 \\
\hline $\begin{array}{l}\text { Revenues spent to reduce accidents and } \\
\text { improve safety }\end{array}$ & $--^{c}$ & 56 & 54 & 62 & 63 & 64 & 64 & 65 & 66 & 71 & 73 & $17^{* *}$ & 1 \\
\hline Revenues spent to reduce congestion & $--^{d}$ & $--^{d}$ & $--^{d}$ & $--^{d}$ & $--^{d}$ & $--^{d}$ & $--^{d}$ & $--^{d}$ & $--^{d}$ & 70 & 71 & $--^{d}$ & $>1$ \\
\hline
\end{tabular}

** Statistically significant at $p<0.01$.

a Sum of those who "strongly" or "somewhat" supported the option.

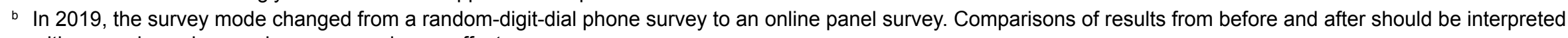
with care, since changes in survey mode can affect responses.

c This option was not included in the 2010 survey.

d This option was added in 2019.

Note: The test of two proportions was used to check if there is a statistically significant difference in support for the different tax options from 2011 to 2020 and from 2019 to 2020 . 


\section{SUPPORT FOR SPENDING SOME GAS TAX REVENUES ON PUBLIC TRANSIT}

Another survey question probed support for spending some gas tax revenue on public transit. The question was worded as follows:

Some people say that money from gas taxes should only be spent on roads and highways, since drivers pay the tax. Other people say gas tax money should be used to pay for public transit in addition to roads and highways, because transit helps reduce traffic congestion and wear-and-tear on the roads. Would you support or oppose spending some gas tax money on public transit? ${ }^{14}$

More than two-thirds of respondents $(71 \%)$ agreed with the concept of using some gas tax revenue to support public transit.

Tables 16 to 19 compare how different subgroups answer the question. Unlike many other tax-related questions in this survey, this question generated many statistically significant variations of ten percentage points or more between subgroups. In fact, there are significant differences subgroups in most categories (age, income, etc.). The subgroups of respondents at least 10 percentage points more likely to support the concept were female, Black/African-American or of "other" race, of Latino/Hispanic origin/descent, employed or unemployed but looking for work, living in households with annual incomes from $\$ 0$ to $\$ 50,000$, from 18 to 24 years old, leaned to the Democratic party or were partyindependent, did not drive, had used transit in the preceding month, and lived in an urban or suburban community. 


\section{Table 16. Support for Spending Some Gas Tax Revenue for Transit, by Sociodemographic Characteristics}

\begin{tabular}{|c|c|}
\hline Subgroup & $\begin{array}{l}\text { Support for using gas tax } \\
\text { revenues for transit (\%) }\end{array}$ \\
\hline All respondents & 71 \\
\hline \multicolumn{2}{|l|}{ Gender } \\
\hline Male & 66 \\
\hline Female & $76^{\star *}$ \\
\hline \multicolumn{2}{|l|}{ Race } \\
\hline White & 68 \\
\hline Black/African-American only & $82^{* *}$ \\
\hline Asian/Asian-American only & 75 \\
\hline Other & $78^{* *}$ \\
\hline \multicolumn{2}{|l|}{ Of Latino/Hispanic descent } \\
\hline Yes & 83 \\
\hline No & $68^{* *}$ \\
\hline \multicolumn{2}{|l|}{ Education } \\
\hline High school graduate or less & 76 \\
\hline More than high school & $68^{* *}$ \\
\hline \multicolumn{2}{|l|}{ Employment status } \\
\hline Working for pay & 74 \\
\hline Unemployed, but looking for work & 78 \\
\hline Not working by choice (retired, etc.) & $64^{* *}$ \\
\hline \multicolumn{2}{|l|}{ Income (annual household) } \\
\hline $0-\$ 50,000$ & 77 \\
\hline$\$ 50,001-\$ 100,000$ & $64^{* *}$ \\
\hline$\$ 100,001+$ & $68^{* *}$ \\
\hline \multicolumn{2}{|l|}{ Age (years) } \\
\hline $18-24$ & 85 \\
\hline $25-54$ & $75^{* *}$ \\
\hline $55+$ & $61^{* *}$ \\
\hline
\end{tabular}

${ }^{* *}$ Statistically significant at $p<0.01$.

Note: The test of two proportions was used to check if there is a statistically significant difference between subgroups. The first subgroup in each category is the reference case against which the proportion of respondents in other subgroups is compared. Values in blue cells are at least ten percentage points different from the reference case. 


\section{Table 17. Support for Spending Some Gas Tax Revenue for Transit, by Political Characteristics (2020)}

\begin{tabular}{lc}
\hline Subgroup & $\begin{array}{c}\text { Support for using gas tax } \\
\text { revenues for transit (\%) }\end{array}$ \\
\hline All respondents & 71 \\
\hline Registered voter & 71 \\
Yes & 74 \\
No & \\
Likely votera & 70 \\
Yes & $75^{*}$ \\
No & \\
Political affiliation & 58 \\
Republican (and lean Republican) & \\
Democrat (and lean Democrat) & $82^{\mathrm{b}}$ \\
Independent, no party affiliation & $70^{* *}$ \\
Some other party & 68 \\
\hline
\end{tabular}

${ }^{*}$ Statistically significant at $p<0.05 .{ }^{* *}$ Statistically significant at $p<0.01$.

a Likely voters are those respondents who said that they are registered voters and that they vote "all of the time" or "most of the time."

b Included registered members of the political party and those respondents who stated that they were independent or a member of another political party but chose to indicate which party they "leaned" towards.

c Registered member of any other party.

Note: The test of two proportions was used to check if there is a statistically significant difference between subgroups. The first subgroup in each category is the reference case against which the proportion of respondents in other subgroups is compared. Values in blue cells are at least ten percentage points different from the reference case. 


\section{Table 18. Support for Spending Some Gas Tax Revenue for Transit, by Travel Behavior}

\begin{tabular}{lc}
\hline Subgroup & $\begin{array}{c}\text { Support for using gas tax } \\
\text { revenues for transit (\%) }\end{array}$ \\
\hline All respondents & 71 \\
\hline Annual miles driven & 72 \\
$1-7,500$ & $65^{* *}$ \\
$7,501-12,500$ & $66^{*}$ \\
$12,501+$ & $85^{* *}$ \\
Don't drive & \\
Miles per gallon ${ }^{\text {a }}$ & 71 \\
$\leq 19$ & 66 \\
$20-30$ & 73 \\
$31+$ & \\
Transit used in last 30 days & 85 \\
Yes & $67^{* *}$ \\
No & \\
Paid a toll to drive on a bridge, tunnel, or road in last 30 days & 75 \\
Yes & $66^{* *}$ \\
No & \\
\hline
\end{tabular}

* Statistically significant at $p<0.05$. * Statistically significant at $p<0.01$.

a Categories drawn from EPA's "SmartWay" vehicle rating system (U.S. Environmental Protection Agency, "SmartWay Vehicle Thresholds MY 2015" (January 2014), https://nepis.epa.gov/Exe/ZyPURL.cgi?Dockey=P100HP2R.TXT.

Note: The test of two proportions was used to check if there is a statistically significant difference between support levels among subgroups. The first subgroup listed in each category is the reference case for the test; the proportion of respondents who supported the individual policies in each of the other subgroups within that category is compared to the reference case.

\section{Table 19. Support for Spending Some Gas Tax Revenue for Transit, by Census} Region and Community Type

\begin{tabular}{lc}
\hline Subgroup & $\begin{array}{c}\text { Support for using gas tax } \\
\text { revenues for transit (\%) }\end{array}$ \\
\hline All respondents & 71 \\
\hline Census region & 75 \\
Northeast & 71 \\
Midwest & $70^{\star}$ \\
South & 71 \\
West & \\
Community type (self-reported) & 81 \\
Urban & $71^{* *}$ \\
Suburban & $66^{\star *}$ \\
Small town & $58^{* *}$ \\
Rural & \\
\hline
\end{tabular}

${ }^{*}$ Statistically significant at $p<0.05 .{ }^{* *}$ Statistically significant at $p<0.01$.

Note: The test of two proportions was used to check if there is a statistically significant difference between subgroups. The first subgroup in each category is the reference case against which the proportion of respondents in other subgroups is compared. Values in blue cells are at least ten percentage points different from the reference case. 


\section{FINDINGS ABOUT MILEAGE FEES}

The survey asked several types of questions related to mileage fees, including respondents' opinions about privacy and fairness, their support for two variants on replacing the gas tax with a mileage fee, opinion about whether EVs should pay the same rate as gas and diesel vehicles, support for several versions of a "business road-use fee" assessed on commercial travel, and their preferred way to pay for a mileage fee.

\section{OPINIONS ABOUT PRIVACY AND FAIRNESS}

The survey asked respondents one question related to potential privacy concerns and two related to their views on the equity of mileage taxes as compared to gas taxes.

The privacy question was worded as follows: "How much do you agree or disagree with the following statement? I'm already tracked everywhere I go through my phone, so having my mileage tracked for a mileage fee wouldn't really bother me." Forty-five percent agreed with this statement about privacy concerns, while $55 \%$ said that they disagreed, implying that they would have privacy concerns. Tables $20-23$ present the analysis of agreement among different subgroups. Subgroups that were particularly unconcerned included respondents who were aged 18 to 24, working for pay, and living in urban areas.

The first question on fairness asked respondents to choose which of two statements was closer to their opinion:

- A mileage fee is MORE fair than the gas tax because everyone pays the same for use of the roads, regardless of vehicle fuel efficiency or vehicle type (electric vs. gas vehicles)

- A mileage fee is LESS fair than the gas tax because the mileage fee doesn't give a break to people who buy cleaner vehicles.

Respondents were evenly split, with $50 \%$ agreeing with each statement. Tables 24 27 present the analysis of agreement among different subgroups, which found only a single case of a characteristic that generated a difference over ten percentage points: respondents who were not in the labor force, as compared to those who were unemployed but looking for work.

The second question on fairness again probed how respondents think about the fairness of mileage fees vs. gas taxes, this time by asking if the rate charged to EV drivers should be less than the rate for gasoline and diesel vehicles, half as much, or zero (EVs would be exempt from paying). Fifty-seven percent of respondents thought EVs should pay a lower rate than gas and diesel vehicles; $20 \%$ wanted to see no charge at all and $37 \%$ thought that EVs should pay half the rate. The other $43 \%$ of respondents thought that EVs should pay the same rate as gas and diesel vehicles. 
This question generated numerous differences among subgroups (Tables 28 through 32). There were differences of ten or more percentage points by gender, race, age, voter registration status, likely voter status, political affiliation, annual miles driven, concern about privacy, and opinion about the fairness of mileage fees as compared to gas taxes. The differences were by far the greatest by political affiliation. For example, $56 \%$ of Republicanleaning respondents but $35 \%$ of Democratic-leaning respondents thought EVs should pay the same rate as gas and diesel vehicles.

\section{Table 20. Percent of Respondents Not Concerned About the Privacy Implications of a Mileage Fee, by Sociodemographic Characteristics ${ }^{a}$}

\begin{tabular}{ll}
\hline Subgroup & Not concerned (\%) \\
\hline All respondents & 45 \\
Gender & 46 \\
Male & 44 \\
Female & \\
Race & 42 \\
White & $58^{* *}$ \\
Black/African-American only & $55^{*}$ \\
Asian/Asian-American only & 43 \\
Other & \\
Of Latino/Hispanic descent & 52 \\
Yes & $43^{* *}$ \\
No & \\
Education & 51 \\
High school graduate or less & $42^{* *}$ \\
More than high school & \\
Employment status & 49 \\
Working for pay & 53 \\
Unemployed, but looking for work & $38^{* *}$ \\
Not working by choice (retired, etc.) & \\
Income (annual household) & \\
$0-\$ 50,000$ & 48 \\
$\$ 50,001-\$ 100,000$ & $41^{* *}$ \\
$\$ 100,001+$ & $43^{*}$ \\
Age (years) & \\
$18-24$ & 56 \\
$25-54$ & $49^{*}$ \\
$55+$ & $37^{* *}$ \\
\hline
\end{tabular}

* Statistically significant at $p<0.05 .{ }^{* *}$ Statistically significant at $p<0.01$.

a Percent of respondents agreeing with this statement: "I'm already tracked everywhere I go through my phone, so having my mileage tracked for a mileage fee wouldn't really both me."

Note: The test of two proportions was used to check if there is a statistically significant difference between subgroups. The first subgroup in each category is the reference case against which the proportion of respondents in other subgroups is compared. Values in blue cells are at least ten percentage points different from the reference case. 


\section{Table 21. Percent of Respondents Not Concerned About the Privacy Implications of a Mileage Fee, by Political Characteristics ${ }^{a}$}

\begin{tabular}{lc}
\hline Subgroup & Agree (\%) \\
\hline All respondents & 45 \\
Registered voter & 46 \\
Yes & 44 \\
No & \\
Likely voter & \\
Yes & 45 \\
No & 45 \\
Political affiliation & \\
Republican (and lean Republican) $)^{c}$ & 42 \\
Democrat (and lean Democrat) & \\
Independent, no party affiliation & $49^{* *}$ \\
Some other party & 44 \\
\hline
\end{tabular}

* Statistically significant at $p<0.05 .{ }^{*}$ Statistically significant at $p<0.01$.

a Percent of respondents agreeing with this statement: "I'm already tracked everywhere I go through my phone, so having my mileage tracked for a mileage fee wouldn't really both me."

b Likely voters are those respondents who said that they are registered voters and that they vote "all of the time" or "most of the time."

c Included registered members of the political party and those respondents who stated that they were independent or a member of another political party but chose to indicate which party they "leaned" towards.

d Registered member of any other party.

Note: The test of two proportions was used to check if there is a statistically significant difference between subgroups. The first subgroup in each category is the reference case against which the proportion of respondents in other subgroups is compared. Values in blue cells are at least ten percentage points different from the reference case. 
Table 22. Percent of Respondents Not Concerned About the Privacy Implications of a Mileage Fee, by Travel Behavior ${ }^{\mathrm{a}}$

\begin{tabular}{lc}
\hline Subgroup & Agree (\%) \\
\hline All respondents & 45 \\
\hline Annual miles driven & 47 \\
$1-7,500$ & 44 \\
$7,501-12,500$ & $38^{* *}$ \\
$12,501+$ & 48 \\
Don't drive & \\
Miles per gallon ${ }^{b}$ & 45 \\
$\leq 19$ & 43 \\
$20-30$ & 46 \\
$31+$ & \\
Transit used in last 30 days & 55 \\
Yes & $42^{* *}$ \\
No & \\
Paid a toll to drive on a bridge, tunnel, or road in last 30 days & 50 \\
Yes & $43^{* *}$ \\
No & \\
\hline
\end{tabular}

** Statistically significant at $p<0.01$.

a Percent of respondents agreeing with this statement: "I'm already tracked everywhere I go through my phone, so having my mileage tracked for a mileage fee wouldn't really both me."

b Categories drawn from EPA's "SmartWay" vehicle rating system (U.S. Environmental Protection Agency, "SmartWay Vehicle Thresholds MY 2015" (January 2014), https://nepis.epa.gov/Exe/ZyPURL.cgi?Dockey=P100HP2R.TXT.

Note: The test of two proportions was used to check if there is a statistically significant difference between subgroups. The first subgroup in each category is the reference case against which the proportion of respondents in other subgroups is compared. Values in blue cells are at least ten percentage points different from the reference case.

\section{Table 23. Percent of Respondents Not Concerned About the Privacy Implications of a Mileage Fee, by Census Region and Community Type ${ }^{a}$}

\begin{tabular}{lc}
\hline Subgroup & Agree (\%) \\
\hline All respondents & 45 \\
\hline Census region & \\
Northeast & 48 \\
Midwest & 42 \\
South & 45 \\
West & 46 \\
Community type (self-reported) & \\
Urban & 55 \\
Suburban & $44^{* *}$ \\
Small town & $34^{* *}$ \\
Rural & $39^{* *}$ \\
\hline
\end{tabular}

** Statistically significant at $p<0.01$.

a Percent of respondents agreeing with this statement: "I'm already tracked everywhere I go through my phone, so having my mileage tracked for a mileage fee wouldn't really both me."

Note: The test of two proportions was used to check if there is a statistically significant difference between subgroups.

The first subgroup in each category is the reference case against which the proportion of respondents in other

subgroups is compared. Values in blue cells are at least ten percentage points different from the reference case. 
Table 24. Respondents' Opinion About Whether Mileage Fees are More or Less Fair than Gas Taxes, by Sociodemographic Characteristics ${ }^{a}$

\begin{tabular}{|c|c|c|}
\hline Subgroup & More Fair (\%) & Less Fair (\%) \\
\hline All respondents & 50 & 50 \\
\hline \multicolumn{3}{|l|}{ Gender } \\
\hline Male & 51 & 49 \\
\hline Female & 49 & 51 \\
\hline \multicolumn{3}{|l|}{ Race } \\
\hline White & 51 & 49 \\
\hline Black/African-American only & 48 & 52 \\
\hline Asian/Asian-American only & 51 & 49 \\
\hline Other & 46 & 54 \\
\hline \multicolumn{3}{|l|}{ Of Latino/Hispanic descent } \\
\hline Yes & 45 & 55 \\
\hline No & $51^{* *}$ & $49^{* *}$ \\
\hline \multicolumn{3}{|l|}{ Education } \\
\hline High school graduate or less & 48 & 52 \\
\hline More than high school & $52^{*}$ & $48^{*}$ \\
\hline \multicolumn{3}{|l|}{ Employment status } \\
\hline Working for pay & 49 & 51 \\
\hline Unemployed, but looking for work & $42^{*}$ & $58^{\star}$ \\
\hline Not working by choice (retired, etc.) & $55^{\star *}$ & $45^{\star *}$ \\
\hline \multicolumn{3}{|l|}{ Income (annual household) } \\
\hline $0-\$ 50,000$ & 48 & 52 \\
\hline$\$ 50,001-\$ 100,000$ & 53 & 47 \\
\hline$\$ 100,001+$ & 51 & 49 \\
\hline \multicolumn{3}{|l|}{ Age (years) } \\
\hline $18-24$ & 47 & 53 \\
\hline $25-54$ & 48 & 52 \\
\hline $55+$ & $55^{*}$ & $45^{\star}$ \\
\hline
\end{tabular}

* Statistically significant at $p<0.05$. ** Statistically significant at $p<0.01$.

a Respondents were asked which statement is closer to their opinion: "A mileage fee is MORE fair than the gas tax because everyone pays the same for use of the roads, regardless of vehicle fuel efficiency or vehicle type (electric vs. gas vehicles)" or "A mileage fee is LESS fair than the gas tax because the mileage fee doesn't give a break to people who buy cleaner vehicles."

Note: The test of two proportions was used to check if there is a statistically significant difference between subgroups. The first subgroup in each category is the reference case against which the proportion of respondents in other subgroups is compared. 
Table 25. Respondents' Opinion About Whether Mileage Fees are More or Less Fair than Gas Taxes, by Political Characteristics ${ }^{a}$

\begin{tabular}{lcc}
\hline Subgroup & More Fair (\%) & Less Fair (\%) \\
\hline All respondents & 50 & 50 \\
Registered voter & 51 & 49 \\
$\quad$ Yes & 47 & 53 \\
No & & \\
Likely voter $^{b}$ & 51 & 49 \\
Yes & 48 & 52 \\
No & & \\
Political affiliation & 53 & 47 \\
Republican (and lean Republican) & \multicolumn{1}{c}{5} \\
Democrat (and lean Democrat) & $49^{*}$ & $51^{*}$ \\
Independent, no party affiliation & $46^{*}$ & $54^{*}$ \\
Some other party & & 49 \\
\hline
\end{tabular}

* Statistically significant at $p<0.05 .{ }^{*}$ Statistically significant at $p<0.01$.

a Respondents were asked which statement is closer to their opinion: "A mileage fee is MORE fair than the gas tax because everyone pays the same for use of the roads, regardless of vehicle fuel efficiency or vehicle type (electric vs. gas vehicles)" or "A mileage fee is LESS fair than the gas tax because the mileage fee doesn't give a break to people who buy cleaner vehicles."

b Likely voters are those respondents who said that they are registered voters and that they vote "all of the time" or "most of the time."

c Included registered members of the political party and those respondents who stated that they were independent or a member of another political party but chose to indicate which party they "leaned" towards.

d Registered member of any other party.

Note: The test of two proportions was used to check if there is a statistically significant difference between subgroups. The first subgroup in each category is the reference case against which the proportion of respondents in other subgroups is compared. 


\section{Table 26. Respondents' Opinion About Whether Mileage Fees are More or Less Fair than Gas Taxes, by Travel Behaviora}

\begin{tabular}{lcc}
\hline Subgroup & More Fair (\%) & Less Fair (\%) \\
\hline All respondents & 50 & 50 \\
Annual miles driven & 50 & 50 \\
$1-7,500$ & 52 & 48 \\
$7,501-12,500$ & 48 & 52 \\
$12,501+$ & 49 & 51 \\
$\quad$ Don't drive & & \\
Miles per gallon ${ }^{\text {b }}$ & 51 & 49 \\
$\leq 19$ & 52 & 48 \\
$20-30$ & 46 & 54 \\
$31+$ & & 54 \\
Transit used in last 30 days & 46 & $49^{*}$ \\
Yes & $51^{*}$ & 50 \\
No & & 49 \\
Paid a toll to drive on a bridge, tunnel, or road in last 30 days & 50 & \\
Yes & 51 & \\
No & & \\
\hline
\end{tabular}

* Statistically significant at $p<0.05 .{ }^{* *}$ Statistically significant at $p<0.01$.

a Respondents were asked which statement is closer to their opinion: "A mileage fee is MORE fair than the gas tax because everyone pays the same for use of the roads, regardless of vehicle fuel efficiency or vehicle type (electric vs. gas vehicles)" or "A mileage fee is LESS fair than the gas tax because the mileage fee doesn't give a break to people who buy cleaner vehicles."

b Categories drawn from EPA's "SmartWay" vehicle rating system (U.S. Environmental Protection Agency, "SmartWay Vehicle Thresholds MY 2015” (January 2014), https://nepis.epa.gov/Exe/ZyPURL.cgi?Dockey=P100HP2R.TXT.

Note: The test of two proportions was used to check if there is a statistically significant difference between subgroups. The first subgroup in each category is the reference case against which the proportion of respondents in other subgroups is compared. 


\section{Table 27. Respondents' Opinion About Whether Mileage Fees are More or Less Fair than Gas Taxes, by Census Region and Community Type ${ }^{a}$}

\begin{tabular}{lcc}
\hline Subgroup & More Fair (\%) & Less Fair (\%) \\
\hline All respondents & 50 & 50 \\
Census region & 50 & 50 \\
$\quad$ Northeast & 51 & 49 \\
Midwest & 49 & 51 \\
South & 52 & 48 \\
West & & \\
Community type (self-reported) & 52 & 48 \\
Urban & 50 & 50 \\
Suburban & 51 & 49 \\
Small town & 56 & 54 \\
Rural & 46 & \\
\hline
\end{tabular}

* Statistically significant at $p<0.05 .{ }^{*}$ Statistically significant at $p<0.01$.

a Respondents were asked which statement is closer to their opinion: "A mileage fee is MORE fair than the gas tax because everyone pays the same for use of the roads, regardless of vehicle fuel efficiency or vehicle type (electric vs. gas vehicles)" or "A mileage fee is LESS fair than the gas tax because the mileage fee doesn't give a break to people who buy cleaner vehicles."

Note: The test of two proportions was used to check if there is a statistically significant difference between subgroups. The first subgroup in each category is the reference case against which the proportion of respondents in other subgroups is compared. 
Table 28. Preferred Mileage Fee Rate for Electric Vehicles, as Compared to the Rate for Gas and Diesel Vehicles, by Sociodemographics ${ }^{a}(2020)$

\begin{tabular}{|c|c|c|c|}
\hline Subgroup & Same rate $(\%)$ & Half the rate $(\%)$ & Free $(\%)$ \\
\hline All respondents & 43 & 37 & 20 \\
\hline \multicolumn{4}{|l|}{ Gender } \\
\hline Male & 47 & 31 & 22 \\
\hline Female & $39^{* *}$ & $43^{* *}$ & $19^{*}$ \\
\hline \multicolumn{4}{|l|}{ Race } \\
\hline White & 45 & 33 & 22 \\
\hline Black/African-American only & $37^{* *}$ & $44^{* *}$ & 19 \\
\hline Asian/Asian-American only & $36^{*}$ & $46^{* *}$ & 18 \\
\hline Other & $38^{*}$ & $48^{* *}$ & $14^{* *}$ \\
\hline \multicolumn{4}{|l|}{ Of Latino/Hispanic descent } \\
\hline Yes & 39 & 42 & 19 \\
\hline No & $44^{*}$ & $35^{\star *}$ & 21 \\
\hline \multicolumn{4}{|l|}{ Education } \\
\hline High school graduate or less & 42 & 37 & 21 \\
\hline More than high school & 43 & 37 & 20 \\
\hline \multicolumn{4}{|l|}{ Employment status } \\
\hline Working for pay & 42 & 38 & 20 \\
\hline Unemployed, but looking for work & $33^{* *}$ & $46^{* *}$ & 21 \\
\hline Not working by choice (retired, etc.) & $48^{* *}$ & $31^{* *}$ & 21 \\
\hline \multicolumn{4}{|l|}{ Income (annual household) } \\
\hline $0-\$ 50,000$ & 41 & 36 & 23 \\
\hline$\$ 50,001-\$ 100,000$ & 46 & 36 & $18^{*}$ \\
\hline$\$ 100,001+$ & 43 & 38 & $18^{*}$ \\
\hline \multicolumn{4}{|l|}{ Age (years) } \\
\hline $18-24$ & 39 & 47 & 13 \\
\hline $25-54$ & 39 & $40^{* \star}$ & $21^{* *}$ \\
\hline $55+$ & $49^{* *}$ & $29^{* \star}$ & $22^{\star \star}$ \\
\hline
\end{tabular}

* Statistically significant at $p<0.05$. ** Statistically significant at $p<0.01$.

a The question asked: "A different variation on the mileage fee concept is to replace the gas tax with a mileage fee of one penny per mile for all gas and diesel vehicles, but with a different rate for all-electric vehicles. What rate per mile do you think electric vehicles should pay?"

Note: The test of two proportions was used to check if there is a statistically significant difference between subgroups. The first subgroup in each category is the reference case against which the proportion of respondents in other subgroups is compared. Values in blue cells are at least ten percentage points different from the reference case. 
Table 29. Preferred Mileage Fee Rate for Electric Vehicles, as Compared to the Rate for Gas and Diesel Vehicles, by Political Characteristics ${ }^{a}$

\begin{tabular}{|c|c|c|c|}
\hline Subgroup & Same rate $(\%)$ & Half the rate $(\%)$ & Free $(\%)$ \\
\hline All respondents & 43 & 37 & 20 \\
\hline \multicolumn{4}{|l|}{ Registered voter } \\
\hline Yes & 45 & 36 & 19 \\
\hline No & $34^{* *}$ & $41^{*}$ & $25^{* *}$ \\
\hline \multicolumn{4}{|l|}{ Likely voter ${ }^{b}$} \\
\hline Yes & 47 & 34 & 18 \\
\hline No & $32^{* *}$ & $43^{* *}$ & $25^{\star \star}$ \\
\hline \multicolumn{4}{|l|}{ Political affiliation } \\
\hline Republican (and lean Republican) & 56 & 27 & 17 \\
\hline Democrat (and lean Democrat) ${ }^{c}$ & $35^{* *}$ & $44^{* *}$ & $21^{*}$ \\
\hline Independent, no party affiliation & $36^{* *}$ & $37^{* *}$ & $27^{* *}$ \\
\hline Some other party ${ }^{d}$ & $33^{* *}$ & 40 & 27 \\
\hline
\end{tabular}

* Statistically significant at $p<0.05$. ** Statistically significant at $p<0.01$.

a The question asked: "A different variation on the mileage fee concept is to replace the gas tax with a mileage fee of one penny per mile for all gas and diesel vehicles, but with a different rate for all-electric vehicles. What rate per mile do you think electric vehicles should pay?"

b Likely voters are those respondents who said that they are registered voters and that they vote "all of the time" or "most of the time."

c Included registered members of the political party and those respondents who stated that they were independent or a member of another political party but chose to indicate which party they "leaned" towards.

d Registered member of any other party.

Note: The test of two proportions was used to check if there is a statistically significant difference between subgroups.

The first subgroup in each category is the reference case against which the proportion of respondents in other

subgroups is compared. Values in blue cells are at least ten percentage points different from the reference case. 
Table 30. Preferred Mileage Fee Rate for Electric Vehicles, as Compared to the Rate for Gas and Diesel Vehicles, by Travel Behavior ${ }^{a}$

\begin{tabular}{lccc}
\hline Subgroup & Same rate (\%) & Half the rate (\%) & Free (\%) \\
\hline All respondents & 43 & 37 & 20 \\
Annual miles driven & & & \\
$\quad 1-7,500$ & 42 & 40 & 18 \\
$7,501-12,500$ & 46 & $34^{*}$ & 19 \\
$12,501+$ & $50^{* *}$ & $29^{* *}$ & 20 \\
$\quad$ Don't drive & $35^{*}$ & 35 & $29^{* *}$ \\
Miles per gallon ${ }^{\text {b }}$ & & & \\
$\leq 19$ & 51 & 33 & 16 \\
$20-30$ & $43^{* *}$ & 37 & 20 \\
$31+$ & $40^{* *}$ & $41^{* *}$ & 19 \\
Transit used in last 30 days & & & 23 \\
Yes & 36 & 41 & 20 \\
No & $45^{* *}$ & $35^{* *}$ & 18 \\
Paid a toll to drive on a bridge, tunnel, or road in last 30 days & & & 19 \\
Yes & 43 & 39 & \\
No & 45 & 36 & \\
\hline
\end{tabular}

* Statistically significant at $p<0.05$.

a The question asked: "A different variation on the mileage fee concept is to replace the gas tax with a mileage fee of one penny per mile for all gas and diesel vehicles, but with a different rate for all-electric vehicles. What rate per mile do you think electric vehicles should pay?"

b Categories drawn from EPA's "SmartWay" vehicle rating system (U.S. Environmental Protection Agency, "SmartWay Vehicle Thresholds MY 2015" (January 2014), https://nepis.epa.gov/Exe/ZyPURL.cgi?Dockey=P100HP2R.TXT.

Note: The test of two proportions was used to check if there is a statistically significant difference between subgroups. The first subgroup in each category is the reference case against which the proportion of respondents in other subgroups is compared. Values in blue cells are at least ten percentage points different from the reference case. 
Table 31. Preferred Mileage Fee Rate for Electric Vehicles, as Compared to the Rate for Gas and Diesel Vehicles, by Census Region and Community Type ${ }^{a}$

\begin{tabular}{lccc}
\hline Subgroup & Same rate $(\%)$ & Half the rate $(\%)$ & Free $(\%)$ \\
\hline All respondents & 43 & 37 & 20 \\
Census region & & & \\
$\quad$ Northeast & 41 & 38 & 21 \\
Midwest & 42 & 34 & 23 \\
South & 43 & 38 & 19 \\
$\quad$ West & 45 & 34 & 21 \\
Community type (self-reported) & & & \\
Urban & 43 & 38 & 19 \\
Suburban & 41 & 36 & $23^{*}$ \\
Small town & 42 & 38 & 20 \\
Rural & $50^{*}$ & 33 & 17 \\
\hline
\end{tabular}

* Statistically significant at $p<0.05 .{ }^{* *}$ Statistically significant at $p<0.01$.

a The question asked: "A different variation on the mileage fee concept is to replace the gas tax with a mileage fee of one penny per mile for all gas and diesel vehicles, but with a different rate for all-electric vehicles. What rate per mile do you think electric vehicles should pay?"

Note: The test of two proportions was used to check if there is a statistically significant difference between subgroups. The first subgroup in each category is the reference case against which the proportion of respondents in other subgroups is compared.

\section{Table 32. Preferred Mileage Fee Rate for Electric Vehicles, as Compared to the Rate for Gas and Diesel Vehicles, by Opinions About Mileage Fees ${ }^{a}$}

\begin{tabular}{lccc}
\hline Subgroup & $\begin{array}{c}\text { Same rate } \\
(\%)\end{array}$ & $\begin{array}{c}\text { Half the rate } \\
(\%)\end{array}$ & $\begin{array}{c}\text { Free } \\
(\%)\end{array}$ \\
\hline All respondents & 43 & 37 & 20 \\
\hline Agreement with statement that mileage fees are not a privacy concern & & & \\
Agree (somewhat or strongly) & 44 & 41 & 15 \\
$\quad$ Disagree (somewhat or strongly) & 42 & $33^{* *}$ & $25^{* *}$ \\
Opinion about the fairness of mileage fees compared to gas taxes ${ }^{\mathrm{b}}$ & & & \\
A mileage fee is more fair & 49 & 36 & 15 \\
A mileage fee is less fair & $37^{* *}$ & 37 & $26^{* *}$ \\
\hline
\end{tabular}

** Statistically significant at $p<0.01$.

a The question asked: "A different variation on the mileage fee concept is to replace the gas tax with a mileage fee of one penny per mile for all gas and diesel vehicles, but with a different rate for all-electric vehicles. What rate per mile do you think electric vehicles should pay?"

b Percent of respondents somewhat or strongly agreeing or disagreeing with this statement: "l'm already tracked everywhere I go through my phone, so having my mileage tracked for a mileage fee wouldn't really both me."

c Respondents were asked which statement is closer to their opinion: "A mileage fee is MORE fair than the gas tax because everyone pays the same for use of the roads, regardless of vehicle fuel efficiency or vehicle type (electric vs. gas vehicles)" or "A mileage fee is LESS fair than the gas tax because the mileage fee doesn't give a break to people who buy cleaner vehicles."

Note: The test of two proportions was used to check if there is a statistically significant difference between subgroups.

The first subgroup in each category is the reference case against which the proportion of respondents in other subgroups is compared. Values in blue cells are at least ten percentage points different from the reference case. 


\section{SUPPORT FOR REPLACING THE GAS TAX WITH A MILEAGE FEE}

Overall, $45 \%$ of respondents supported replacing the gas tax with a flat-rate mileage fee of one cent per mile, and $49 \%$ supported a "green" version, for which the average rate would be one cent per mile, but vehicles that pollute less would be charged less and vehicles that pollute more would be charged more (Figure 7 ).

Tables 33 through 37 look at support for the mileage fees by subgroup. The respondents who were statistically significantly more likely to support both mileage fee variants by ten points or more were Black/African-American, of Latino/Hispanic origin/descent, working for pay, $18-25$ years old, drove from 1 to 7,500 miles per year, had ridden transit in the past 30 days, lived in urban communities, and agreed with the statement that, "I'm already tracked everywhere I go through my phone, so having my mileage tracked for a mileage fee wouldn't really both me." The size of the differences was by far the biggest according to concern about tracking. Respondents who were not concerned about being tracked were 44 percentage points more likely to support the flat mileage fee and 37 percentage points more likely to support the green mileage fee.

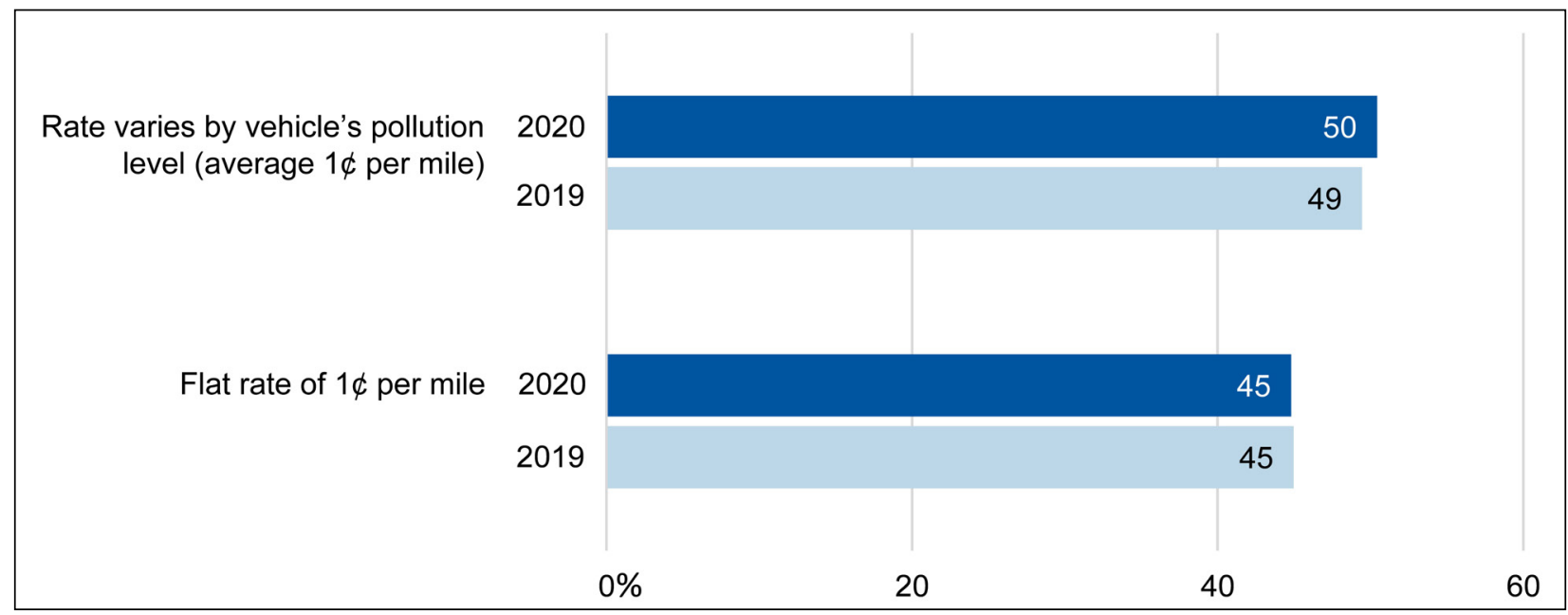

Figure 7. Support ${ }^{\mathrm{a}}$ for the Mileage Fee Options, $2019-2020$

a "Support" is the sum of those who "strongly" or "somewhat" supported the tax option. 


\section{Table 33. Support ${ }^{\text {a }}$ for the Mileage Fee Options, by Sociodemographic Characteristics}

\begin{tabular}{|c|c|c|}
\hline Subgroup & Flat $(\%)$ & Green (\%) \\
\hline All respondents & 45 & 49 \\
\hline \multicolumn{3}{|l|}{ Gender } \\
\hline Male & 45 & 45 \\
\hline Female & 45 & $54^{* *}$ \\
\hline \multicolumn{3}{|l|}{ Race } \\
\hline White & 43 & 46 \\
\hline Black/African-American only & $53^{* *}$ & $60^{* *}$ \\
\hline Asian/Asian-American only & 50 & $63^{* *}$ \\
\hline Other & 47 & $54^{*}$ \\
\hline \multicolumn{3}{|l|}{ Of Latino/Hispanic origin/descent } \\
\hline Yes & 53 & 58 \\
\hline No & $43^{* *}$ & $47^{* *}$ \\
\hline \multicolumn{3}{|l|}{ Education } \\
\hline High school graduate or less & 48 & 50 \\
\hline More than high school & $43^{*}$ & 49 \\
\hline \multicolumn{3}{|l|}{ Employment status } \\
\hline Working for pay & 48 & 54 \\
\hline Unemployed, but looking for work & 51 & 56 \\
\hline Not working by choice (retired, etc.) & $38^{* *}$ & $40^{* *}$ \\
\hline \multicolumn{3}{|l|}{ Income (annual household) } \\
\hline $0-\$ 50,000$ & 46 & 49 \\
\hline$\$ 50,001-\$ 100,000$ & 42 & 46 \\
\hline$\$ 100,001+$ & 47 & $54^{*}$ \\
\hline \multicolumn{3}{|l|}{ Age (years) } \\
\hline $18-24$ & 58 & 58 \\
\hline $25-54$ & $47^{* *}$ & 55 \\
\hline $55+$ & $37^{\star *}$ & $39^{* *}$ \\
\hline
\end{tabular}

* Statistically significant at $p<0.05$. ${ }^{*}$ Statistically significant at $p<0.01$.

a Sum of those who "strongly" or "somewhat" supported the option.

Note: The test of two proportions was used to check if there is a statistically significant difference between subgroups. The first subgroup in each category is the reference case against which the proportion of respondents in other subgroups is compared. Values in blue cells are at least ten percentage points different from the reference case. 
Table 34. Support ${ }^{\mathrm{a}}$ for the Mileage Fee Options, by Political Characteristics

\begin{tabular}{|c|c|c|}
\hline Subgroup & Flat $(\%)$ & Green $(\%)$ \\
\hline All respondents & 45 & 49 \\
\hline \multicolumn{3}{|l|}{ Registered voter } \\
\hline Yes & 45 & 50 \\
\hline No & 47 & 47 \\
\hline \multicolumn{3}{|l|}{ Likely voter ${ }^{b}$} \\
\hline Yes & 45 & 49 \\
\hline No & 46 & 50 \\
\hline \multicolumn{3}{|l|}{ Political affiliation } \\
\hline Republican (and lean Republican) ${ }^{c}$ & 42 & 40 \\
\hline Democrat (and lean Democrat) ${ }^{c}$ & $48^{*}$ & $57^{* *}$ \\
\hline Independent, no party affiliation & 44 & $49^{* *}$ \\
\hline Some other party ${ }^{d}$ & 32 & 35 \\
\hline
\end{tabular}

* Statistically significant at $p<0.05$. ${ }^{*}$ Statistically significant at $p<0.01$.

a Sum of those who "strongly" or "somewhat" supported the option.

b Likely voters are those respondents who said that they are registered voters and that they vote "all of the time" or "most of the time."

c Included registered members of the political party and those respondents who stated that they were independent or a member of another political party but chose to indicate which party they "leaned" towards.

d Registered member of any other party.

Note: The test of two proportions was used to check if there is a statistically significant difference between subgroups. The first subgroup in each category is the reference case against which the proportion of respondents in other subgroups is compared. Values in blue cells are at least ten percentage points different from the reference case. 
Table 35. Support ${ }^{\mathrm{a}}$ for the Mileage Fee Options, by Travel Behavior

\begin{tabular}{|c|c|c|}
\hline Subgroup & Flat $(\%)$ & Green (\%) \\
\hline All respondents & 45 & 49 \\
\hline \multicolumn{3}{|c|}{ Annual miles driven } \\
\hline $1-7,500$ & 48 & 52 \\
\hline $7,501-12,500$ & $37^{* *}$ & $42^{* *}$ \\
\hline $12,501+$ & $39^{* *}$ & $43^{* *}$ \\
\hline Don't drive & $54^{*}$ & $58^{*}$ \\
\hline \multicolumn{3}{|l|}{ Miles per gallon ${ }^{\mathrm{b}}$} \\
\hline$\leq 19$ & 47 & 49 \\
\hline $20-30$ & $41^{*}$ & 45 \\
\hline $31+$ & 42 & 54 \\
\hline \multicolumn{3}{|c|}{ Transit used in last 30 days } \\
\hline Yes & 52 & 61 \\
\hline No & $43^{* *}$ & $46^{* *}$ \\
\hline \multicolumn{3}{|c|}{ Paid a toll to drive on a bridge, tunnel, or road in last 30 days } \\
\hline Yes & 53 & 54 \\
\hline No & $39^{* *}$ & $46^{* *}$ \\
\hline
\end{tabular}

* Statistically significant at $p<0.05$. ** Statistically significant at $p<0.01$.

a Sum of those who "strongly" or "somewhat" supported the option.

b Categories drawn from EPA's "SmartWay" vehicle rating system (U.S. Environmental Protection Agency, "SmartWay Vehicle Thresholds MY 2015" (January 2014), https://nepis.epa.gov/Exe/ZyPURL.cgi?Dockey=P100HP2R.TXT.

Note: The test of two proportions was used to check if there is a statistically significant difference between subgroups. The first subgroup in each category is the reference case against which the proportion of respondents in other subgroups is compared. Values in blue cells are at least ten percentage points different from the reference case.

\section{Table 36. Support ${ }^{\mathrm{a}}$ for the Mileage Fee Options, by Census Region and Community Type}

\begin{tabular}{lcc}
\hline Subgroup & Flat $(\%)$ & Green $(\%)$ \\
\hline All respondents & 45 & 49 \\
Census region & & \\
Northeast & 49 & 55 \\
Midwest & $41^{* *}$ & $41^{* *}$ \\
South & $43^{*}$ & 51 \\
West & 48 & $48^{*}$ \\
Community type (self-reported) & & \\
Urban & 54 & 63 \\
Suburban & $42^{* *}$ & $49^{* *}$ \\
Small town & $39^{* *}$ & $35^{* *}$ \\
Rural & $40^{* *}$ & $37^{* *}$ \\
\hline
\end{tabular}

* Statistically significant at $p<0.05$. * Statistically significant at $p<0.01$.

a Sum of those who "strongly" or "somewhat" supported the option.

Note: The test of two proportions was used to check if there is a statistically significant difference between subgroups. The first subgroup in each category is the reference case against which the proportion of respondents in other subgroups is compared. Values in blue cells are at least ten percentage points different from the reference case. 


\section{Table 37. Support ${ }^{a}$ for the Mileage Fee Options, by Opinions About Privacy and Fairness}

\begin{tabular}{lcc}
\hline Subgroup & Flat (\%) & Green (\%) \\
\hline All respondents & 45 & 49 \\
Agreement with statement that mileage fees are not a privacy concern & & \\
Agree (somewhat or strongly) & 69 & 70 \\
Disagree (somewhat or strongly) & $25^{* *}$ & $33^{* *}$ \\
Opinion about the fairness of mileage fees compared to gas taxes & & \\
A mileage fee is more fair & 55 & 53 \\
A mileage fee is less fair & $35^{* *}$ & $46^{* *}$ \\
\hline
\end{tabular}

** Statistically significant at $p<0.01$.

a Sum of those who strongly or somewhat supported the option

b Percent of respondents somewhat or strongly agreeing or disagreeing with this statement: "I'm already tracked everywhere I go through my phone, so having my mileage tracked for a mileage fee wouldn't really both me."

c Respondents were asked which statement is closer to their opinion: "A mileage fee is MORE fair than the gas tax because everyone pays the same for use of the roads, regardless of vehicle fuel efficiency or vehicle type (electric vs. gas vehicles)" or "A mileage fee is LESS fair than the gas tax because the mileage fee doesn't give a break to people who buy cleaner vehicles."

Note: The test of two proportions was used to check if there is a statistically significant difference between subgroups. The first subgroup in each category is the reference case against which the proportion of respondents in other subgroups is compared. Values in blue cells are at least ten percentage points different from the reference case.

\section{PREFERRED WAY TO PAY FOR MILEAGE FEES}

A final question about mileage fees asked respondents to select their preferred way to pay for the fees, should these be introduced. The options were to pay at the time of gas purchase or when charging an electric vehicle, pay a monthly bill, or pay an annual bill.

The most popular option, selected by $47 \%$ of respondents, was to "Pay each time I purchase gas/diesel or charge an electric vehicle." The same pattern holds for the subgroups; paying with each gas purchase or charging session was the most popular option for every subgroup (Tables 38 through 42). Comparing the billing options, a monthly bill was preferred by somewhat more than an annual bill ( $30 \%$ vs. $23 \%)$, and all but two of the subgroups tested had the same relative preferences.

As the analysis of subgroups in Tables 38 through 42 shows, there were very few subgroups with a meaningfully higher rate of support for any of the options. Where there were differences, these were mostly for the pay-when-refueling-or-charging option. That payment choice was preferred by least ten percentage points among respondents who were men, white, not working by choice, 25 years and older, urban, and concerned about the privacy implications of mileage fees. The only notable differences by characteristic for the monthly and annual billing options related to age, political party, and community type. 
Table 38. Preferred Frequency for Paying a Mileage Fee, by Sociodemographic Characteristics

\begin{tabular}{|c|c|c|c|}
\hline Subgroup & $\begin{array}{c}\text { Annually } \\
(\%)\end{array}$ & $\begin{array}{c}\text { Monthly } \\
(\%)\end{array}$ & $\begin{array}{c}\text { When refueling } \\
(\%)\end{array}$ \\
\hline All respondents & 23 & 30 & 47 \\
\hline \multicolumn{4}{|l|}{ Gender } \\
\hline Male & 19 & 29 & 51 \\
\hline Female & $27^{* *}$ & 32 & $42^{* *}$ \\
\hline \multicolumn{4}{|l|}{ Race } \\
\hline White & 20 & 30 & 50 \\
\hline Black/African-American only & $27^{* *}$ & $36^{*}$ & $37^{* *}$ \\
\hline Asian/Asian-American only & 27 & 31 & 41 \\
\hline Other & $29^{* *}$ & 26 & 45 \\
\hline \multicolumn{4}{|l|}{ Of Latino/Hispanic descent } \\
\hline Yes & 24 & 32 & 43 \\
\hline No & 22 & 30 & 48 \\
\hline \multicolumn{4}{|l|}{ Education } \\
\hline High school graduate or less & 22 & 31 & 47 \\
\hline More than high school & 23 & 30 & 47 \\
\hline \multicolumn{4}{|l|}{ Employment status } \\
\hline Working for pay & 25 & 32 & 43 \\
\hline Unemployed, but looking for work & 24 & 31 & 45 \\
\hline Not working by choice (retired, etc.) & $19^{* *}$ & $28^{*}$ & $53^{* *}$ \\
\hline \multicolumn{4}{|l|}{ Income (annual household) } \\
\hline $0-\$ 50,000$ & 20 & 31 & 48 \\
\hline$\$ 50,001-\$ 100,000$ & 23 & 31 & 47 \\
\hline$\$ 100,001+$ & $27^{* *}$ & 29 & 44 \\
\hline \multicolumn{4}{|l|}{ Age (years) } \\
\hline $18-24$ & 29 & 42 & 29 \\
\hline $25-54$ & 27 & $28^{* *}$ & $45^{\star *}$ \\
\hline $55+$ & $15^{\star *}$ & $30^{* *}$ & $55^{\star *}$ \\
\hline
\end{tabular}

* Statistically significant at $p<0.05 .{ }^{* *}$ Statistically significant at $p<0.01$.

Note: The test of two proportions was used to check if there is a statistically significant difference between subgroups. The first subgroup in each category is the reference case against which the proportion of respondents in other subgroups is compared. Values in blue cells are at least ten percentage points different from the reference case. 


\section{Table 39. Preferred Frequency for Paying a Mileage Fee, by Political Characteristics}

\begin{tabular}{lccc}
\hline Subgroup & $\begin{array}{c}\text { Annually } \\
(\%)\end{array}$ & $\begin{array}{c}\text { Monthly } \\
(\%)\end{array}$ & $\begin{array}{c}\text { When refueling } \\
(\%)\end{array}$ \\
\hline All respondents & 23 & 30 & 47 \\
Registered voter & & & 48 \\
$\quad$ Yes & 23 & 30 & $42^{*}$ \\
$\quad$ No & 23 & $35^{*}$ & 48 \\
Likely voter & & & 44 \\
Yes & 23 & 29 & 47 \\
No & 23 & 33 & 48 \\
Political affiliation & & & 44 \\
Republican (and lean Republican) & 22 & 31 & 38 \\
$\quad$ Democrat (and lean Democrat) & & 30 & \\
Independent, no party affiliation & 22 & 31 & \\
Some other party & 25 & 29 & \\
\hline
\end{tabular}

* Statistically significant at $p<0.05$.

a Likely voters are those respondents who said that they are registered voters and that they vote "all of the time" or "most of the time."

b Included registered members of the political party and those respondents who stated that they were independent or a member of another political party but chose to indicate which party they "leaned" towards.

c Registered member of any other party.

Note: The test of two proportions was used to check if there is a statistically significant difference between subgroups. The first subgroup in each category is the reference case against which the proportion of respondents in other subgroups is compared.

Table 40. Preferred Frequency for Paying a Mileage Fee, by Travel Behavior

\begin{tabular}{lccc}
\hline Subgroup & $\begin{array}{c}\text { Annually } \\
(\%)\end{array}$ & $\begin{array}{c}\text { Monthly } \\
(\%)\end{array}$ & $\begin{array}{c}\text { When refueling } \\
(\%)\end{array}$ \\
\hline All respondents & 23 & 30 & 47 \\
\hline Annual miles driven & & & \\
$1-7,500$ & 23 & 32 & 45 \\
$7,501-12,500$ & 22 & 28 & 50 \\
$12,501+$ & 22 & 28 & 49 \\
$\quad$ Don't drive & 25 & 31 & 44 \\
Miles per gallon ${ }^{\text {a }}$ & & & 43 \\
$\leq 19$ & 22 & 34 & $50^{*}$ \\
$20-30$ & 20 & 29 & 45 \\
$31+$ & 26 & 28 & 41 \\
Transit used in last 30 days & & & $49^{* *}$ \\
Yes & 28 & 31 & 43 \\
No & $21^{* *}$ & 30 & $49^{* *}$ \\
Paid a toll to drive on a bridge, tunnel, or road in last 30 days & & & \\
Yes & 26 & 32 & \\
No & $21^{*}$ & 30 & \\
\hline
\end{tabular}

* Statistically significant at $p<0.05 .{ }^{*}$ Statistically significant at $p<0.01$.

a Categories drawn from EPA's "SmartWay" vehicle rating system (U.S. Environmental Protection Agency, "SmartWay Vehicle Thresholds MY 2015" (January 2014), https://nepis.epa.gov/Exe/ZyPURL.cgi?Dockey=P100HP2R.TXT.

Note: The test of two proportions was used to check if there is a statistically significant difference between subgroups. The first subgroup in each category is the reference case against which the proportion of respondents in other subgroups is compared. 


\section{Table 41. Preferred Frequency for Paying a Mileage Fee, by Census Region and Community Type}

\begin{tabular}{lccc}
\hline Subgroup & $\begin{array}{c}\text { Annually } \\
(\%)\end{array}$ & $\begin{array}{c}\text { Monthly } \\
(\%)\end{array}$ & $\begin{array}{c}\text { When refueling } \\
(\%)\end{array}$ \\
\hline All respondents & 23 & 30 & 47 \\
Census region & & & \\
$\quad$ Northeast & 28 & 29 & 42 \\
$\quad$ Midwest & $20^{* *}$ & 31 & $49^{*}$ \\
South & $22^{* *}$ & 31 & 47 \\
$\quad$ West & $21^{* *}$ & 30 & $49^{*}$ \\
Community type (self-reported) & & & \\
$\quad$ Urban & 27 & 30 & 43 \\
$\quad$ Suburban & $22^{*}$ & 32 & 46 \\
$\quad$ Small town & 23 & 31 & 47 \\
$\quad$ Rural & $16^{* *}$ & 26 & $57^{* *}$ \\
\hline
\end{tabular}

* Statistically significant at $p<0.05 .{ }^{* \star}$ Statistically significant at $p<0.01$.

Note: The test of two proportions was used to check if there is a statistically significant difference between subgroups. The first subgroup in each category is the reference case against which the proportion of respondents in other subgroups is compared.

Table 42. Preferred Frequency for Paying a Mileage Fee, by Opinions About Mileage Fees

\begin{tabular}{lccc}
\hline Subgroup & $\begin{array}{c}\text { Annually } \\
(\%)\end{array}$ & $\begin{array}{c}\text { Monthly } \\
(\%)\end{array}$ & $\begin{array}{c}\text { When refueling } \\
(\%)\end{array}$ \\
\hline All respondents & 23 & 30 & 47 \\
\hline Agreement with statement that mileage fees are not a privacy concern & & & \\
Agree (somewhat or strongly) & 24 & 36 & 41 \\
Disagree (somewhat or strongly) & 22 & $26^{* *}$ & $52^{* *}$ \\
Opinion about the fairness of mileage fees compared to gas taxes ${ }^{\mathrm{b}}$ & & & \\
A mileage fee is more fair & 22 & 32 & 45 \\
A mileage fee is less fair & 23 & $29^{*}$ & 48 \\
\hline
\end{tabular}

* Statistically significant at $p<0.05$. ${ }^{* *}$ Statistically significant at $p<0.01$.

a Percent of respondents agreeing with this statement: "I'm already tracked everywhere I go through my phone, so having my mileage tracked for a mileage fee wouldn't really both me."

b Respondents were asked which statement is closer to their opinion: "A mileage fee is MORE fair than the gas tax because everyone pays the same for use of the roads, regardless of vehicle fuel efficiency or vehicle type (electric vs. gas vehicles)" or "A mileage fee is LESS fair than the gas tax because the mileage fee doesn't give a break to people who buy cleaner vehicles."

Note: The test of two proportions was used to check if there is a statistically significant difference between subgroups. The first subgroup in each category is the reference case against which the proportion of respondents in other subgroups is compared. Values in blue cells are at least ten percentage points different from the reference case.

\section{SUPPORT FOR A BUSINESS ROAD-USE FEE}

New to this year's survey was a question asking respondents about a hypothetical "Business Road-Use Fee" that would be assessed only on miles that commercial vehicles drive on the job. Those vehicles would continue to pay the current gas tax as well. Respondents were 
asked if they would support such a tax on different types of commercial travel: delivery and freight trucks, taxis, and ridehailing vehicles. Support for all three options was just over $50 \%$, with marginally higher support for the fee on deliveries and freight.

As Tables 43 through 47 show, there were very few meaningful differences in support among subgroups. However, those subgroups that had different views were consistently more supportive of fees on all three types of commercial travel. The subgroups that were more supportive were respondents who leaned Democrat, lived in urban areas, and agreed with the statement that, "I'm already tracked everywhere I go through my phone, so having my mileage tracked for a mileage fee wouldn't really bother me."

\section{Table 43. Support ${ }^{a}$ for a Business Road-Use Fee, by Sociodemographic Characteristics}

\begin{tabular}{|c|c|c|c|}
\hline Subgroup & Delivery/Freight (\%) & Taxis (\%) & Ridehail (\%) \\
\hline All respondents & 54 & 52 & 52 \\
\hline \multicolumn{4}{|l|}{ Gender } \\
\hline Male & 54 & 53 & 52 \\
\hline Female & 55 & 52 & 51 \\
\hline \multicolumn{4}{|l|}{ Race } \\
\hline White & 53 & 53 & 50 \\
\hline Black/African-American only & 57 & 53 & $58^{*}$ \\
\hline Asian/Asian-American only & 62 & 57 & 58 \\
\hline Other & 54 & 47 & 49 \\
\hline \multicolumn{4}{|l|}{ Of Latino/Hispanic descent } \\
\hline Yes & 55 & 55 & 52 \\
\hline No & 54 & 51 & 52 \\
\hline \multicolumn{4}{|l|}{ Education } \\
\hline High school graduate or less & 51 & 52 & 53 \\
\hline More than high school & $57^{* *}$ & 53 & 51 \\
\hline \multicolumn{4}{|l|}{ Employment status } \\
\hline Working for pay & 56 & 52 & 53 \\
\hline Unemployed, but looking for work & 55 & 56 & 55 \\
\hline Not working by choice (retired, etc.) & 52 & 51 & 49 \\
\hline \multicolumn{4}{|l|}{ Income (annual household) } \\
\hline $0-\$ 50,000$ & 53 & 54 & 53 \\
\hline$\$ 50,001-\$ 100,000$ & 56 & 53 & 52 \\
\hline$\$ 100,001+$ & 55 & $48^{*}$ & 50 \\
\hline \multicolumn{4}{|l|}{ Age (years) } \\
\hline $18-24$ & 55 & 52 & 53 \\
\hline $25-54$ & 56 & 53 & 52 \\
\hline $55+$ & 52 & 51 & 50 \\
\hline
\end{tabular}

* Statistically significant at $p<0.05 .{ }^{* *}$ Statistically significant at $p<0.01$.

a Sum of those who "strongly" or "somewhat" supported the option.

Note: The test of two proportions was used to check if there is a statistically significant difference between subgroups. The first subgroup in each category is the reference case against which the proportion of respondents in other subgroups is compared. 
Table 44. Support ${ }^{a}$ for a Business Road-Use Fee, by Political Characteristics

\begin{tabular}{lccc}
\hline Subgroup & Delivery/Freight (\%) & Taxis (\%) & Ridehail (\%) \\
\hline All respondents & 54 & 52 & 52 \\
Registered voter & & & 51 \\
$\quad$ Yes & 53 & 52 & $57^{*}$ \\
No & $60^{* *}$ & 55 & \\
Likely voter & & & 51 \\
Yes & 54 & 52 & 52 \\
No & 54 & 53 & \\
Political affiliation & & & 44 \\
Republican (and lean Republican) & & 45 & $57^{* *}$ \\
Democrat (and lean Democrat) & & $58^{* *}$ & $53^{*}$ \\
Independent, no party affiliation & $61^{* *}$ & $53^{*}$ & 50 \\
Some other party & $54^{*}$ & 43 & \\
\hline
\end{tabular}

* Statistically significant at $p<0.05$. ${ }^{*}$ Statistically significant at $p<0.01$.

a Sum of those who "strongly" or "somewhat" supported the option.

b Likely voters are those respondents who said that they are registered voters and that they vote "all of the time" or "most of the time."

c Included registered members of the political party and those respondents who stated that they were independent or a member of another political party but chose to indicate which party they "leaned" towards.

d Registered member of any other party.

Note: The test of two proportions was used to check if there is a statistically significant difference between subgroups. The first subgroup in each category is the reference case against which the proportion of respondents in other subgroups is compared. Values in blue cells are at least ten percentage points different from the reference case. 
Table 45. Support ${ }^{\mathrm{a}}$ for a Business Road-Use Fee, by Travel Behavior

\begin{tabular}{|c|c|c|c|}
\hline Subgroup & Delivery/Freight (\%) & Taxis (\%) & Ridehail (\%) \\
\hline All respondents & 54 & 52 & 52 \\
\hline \multicolumn{4}{|c|}{ Annual miles driven } \\
\hline $1-7,500$ & 55 & 53 & 52 \\
\hline $7,501-12,500$ & 54 & 51 & 50 \\
\hline $12,501+$ & 55 & 48 & 51 \\
\hline Don't drive & 52 & 55 & 55 \\
\hline \multicolumn{4}{|l|}{ Miles per gallon ${ }^{b}$} \\
\hline$\leq 19$ & 52 & 50 & 50 \\
\hline $20-30$ & 53 & 51 & 50 \\
\hline $31+$ & $60^{*}$ & 56 & 53 \\
\hline \multicolumn{4}{|c|}{ Transit used in last 30 days } \\
\hline Yes & 52 & 53 & 53 \\
\hline No & 55 & 52 & 51 \\
\hline \multicolumn{4}{|c|}{ Taxi used in last 30 days } \\
\hline Yes & 61 & 57 & 60 \\
\hline No & 54 & 52 & $51^{*}$ \\
\hline \multicolumn{4}{|c|}{ Ridehail used in last 30 days } \\
\hline Yes & 60 & 55 & 53 \\
\hline No & $53^{*}$ & 52 & 51 \\
\hline \multicolumn{4}{|c|}{ Paid a toll to drive on a bridge, tunnel, or road in last 30 days } \\
\hline Yes & 55 & 49 & 53 \\
\hline No & 55 & 53 & 50 \\
\hline
\end{tabular}

* Statistically significant at $p<0.05$.

a Sum of those who "strongly" or "somewhat" supported the option.

b Categories drawn from EPA's "SmartWay" vehicle rating system (U.S. Environmental Protection Agency, "SmartWay Vehicle Thresholds MY 2015" (January 2014), https://nepis.epa.gov/Exe/ZyPURL.cgi?Dockey=P100HP2R.TXT.

Note: The test of two proportions was used to check if there is a statistically significant difference between subgroups. The first subgroup in each category is the reference case against which the proportion of respondents in other subgroups is compared. 


\section{Table 46. Support ${ }^{\text {a }}$ for a Business Road-Use Fee, by Census Region and Community Type}

\begin{tabular}{lccc}
\hline Subgroup & Delivery/Freight (\%) & Taxis (\%) & Ridehail (\%) \\
\hline All respondents & 54 & 52 & 52 \\
Census region & & & \\
$\quad$ Northeast & 59 & 53 & 56 \\
$\quad$ Midwest & 54 & 54 & 51 \\
South & $52^{*}$ & 51 & $51^{*}$ \\
$\quad$ West & $53^{*}$ & 53 & $50^{*}$ \\
Community type (self-reported) & & & \\
Urban & 57 & 56 & 57 \\
Suburban & 56 & 53 & $51^{*}$ \\
Small town & $46^{* *}$ & $42^{* *}$ & $44^{* *}$ \\
Rural & 52 & 52 & $48^{* *}$ \\
\hline
\end{tabular}

* Statistically significant at $p<0.05$. * Statistically significant at $p<0.01$.

a Sum of those who "strongly" or "somewhat" supported the option.

Note: The test of two proportions was used to check if there is a statistically significant difference between subgroups. The first subgroup in each category is the reference case against which the proportion of respondents in other subgroups is compared. Values in blue cells are at least ten percentage points different from the reference case.

Table 47. Support ${ }^{\text {a }}$ for a Business Road-Use Fee, by Opinions About Mileage Fees

\begin{tabular}{lccc}
\hline Subgroup & Delivery/Freight (\%) & Taxis (\%) & Ridehail (\%) \\
\hline All respondents & 54 & 52 & 52 \\
\hline Agreement with statement that mileage fees are not a privacy concern & & \\
Agree (somewhat or strongly) & 61 & 60 & 62 \\
Disagree (somewhat or strongly) & $49^{* *}$ & $45^{* *}$ & $43^{* *}$ \\
Opinion about the fairness of mileage fees compared to gas taxes & \\
A mileage fee is more fair & 55 & 54 & 54 \\
A mileage fee is less fair & 54 & 50 & $49^{*}$ \\
\hline
\end{tabular}

* Statistically significant at $p<0.05$. ** Statistically significant at $p<0.01$.

a Sum of those who "strongly" or "somewhat" supported the option.

b Percent of respondents agreeing with this statement: "I'm already tracked everywhere I go through my phone, so having my mileage tracked for a mileage fee wouldn't really both me."

c Respondents were asked which statement is closer to their opinion: "A mileage fee is MORE fair than the gas tax because everyone pays the same for use of the roads, regardless of vehicle fuel efficiency or vehicle type (electric vs. gas vehicles)" or "A mileage fee is LESS fair than the gas tax because the mileage fee doesn't give a break to people who buy cleaner vehicles."

Note: The test of two proportions was used to check if there is a statistically significant difference between subgroups. The first subgroup in each category is the reference case against which the proportion of respondents in other subgroups is compared. Values in blue cells are at least ten percentage points different from the reference case. 


\section{CONCLUSIONS}

This section concludes the report with a summary of ten key survey findings on public opinion and knowledge about federal transportation taxes and fees. These findings about public priorities suggest opportunities for policymakers to build support for transportation tax measures through careful program design. The discussion is organized into conclusions about public priorities related to the transportation system, knowledge and opinions about gas taxes, opinions about mileage fees, and variations in opinions among different population subgroups.

\section{PUBLIC PRIORITIES FOR IMPROVING THE TRANSPORTATION SYSTEM}

1. Large majorities value transportation improvements across modes. When respondents were asked to indicate their priorities for improvements to the transportation system, large majorities supported both road and public-transit related options. For example, $75 \%$ of respondents said it was "very" important to maintain and improve roads, streets, highways, and bridges, and $58 \%$ said it was "very" important to maintain and improve public transit.

2. The majority value linking transportation taxes to environmental objectives. For example, the gas tax increase variants that linked the increase to projects reducing air pollution and global warming both had clear majority support ( $56 \%$ and $61 \%$, respectively). Also, the green mileage tax variant was slightly more popular than the flat-rate version (50\% vs. $45 \%$ support), and $57 \%$ of respondents thought that EV drivers should pay a lower rate than that for gasoline and diesel vehicles.

\section{GAS TAXES}

3. Most people do not know how recently the gas tax rate was raised by the federal government or in their state. Only $3 \%$ of respondents knew that the federal gas tax rate was last raised more than 20 years ago, and only $25 \%$ knew approximately when their state had last raised its gas tax rate. About half of respondents said they simply didn't know when the federal and state rates were last raised.

4. Support for raising the gas tax rate depends on how the revenue will be spent. When it comes to earning public support, all gas taxes are not alike. Policymakers can increase support by crafting tax measures that dedicate the revenues to purposes valued by the public. For example, people want better maintenance - and will pay for it. The gas tax variant with proceeds dedicated for maintenance was the most popular variant tested, with $75 \%$ supporting this increase. By comparison, only $44 \%$ supported the "base case" gas tax for which the proceeds would be dedicated more generally to "transportation."

5. Support for raising the gas tax has risen slowly but steadily since 2010 . For all five of the gas tax variants that were tested throughout the survey series, support has risen since 2010. The change ranges from an 8-percentage point increase to a 20-percentage point increase. 


\section{MILEAGE FEES}

6. Roughly half of people support some form of a mileage fee, whether it is assessed on all travel or just on commercial travel. Forty-five percent of respondents supported replacing the gas tax with a flat-rate mileage fee of one cent per mile, and $49 \%$ supported a "green" version for which the average rate would be one cent per mile, but vehicles that pollute less would be charged less and vehicles that pollute more would be charged more. Just over half of respondents also supported a "business road-use fee" assessed on the miles that commercial vehicles drive on the job. (These vehicles would continue to pay the gas tax, too.) Fifty-four percent of respondents supported such a fee on delivery and freight trucks, and $52 \%$ supported such as fee on either taxis or ridehailing vehicles.

7. Three-quarters of people want to pay a mileage fee in small installments instead of paying one large, annual bill. Respondents were asked if they would prefer to pay for mileage fees at the pump or time of vehicle charging, monthly, or annually. The first option was the most popular of the three $(47 \%)$ and the annual billing option the least popular $(23 \%)$.

8. People concerned about privacy are much less likely to support the mileage fee concept. Fifty-five percent of respondents expressed concern with the idea of being tracked for a mileage fee program. This group was considerably less likely to support either the flat-rate or green mileage fees on all travel, or the business road-use fee. The lack of enthusiasm was particularly stark for the flat-rate fee on all travel; here, only $25 \%$ of respondents concerned about tracking supported the fee, as compared to $69 \%$ of respondents who were not concerned about being tracked.

\section{VARIATIONS BY PERSONAL CHARACTERISTICS}

9. Looking across the survey as a whole, there were usually modest differences in opinion related to personal characteristics. We assessed whether responses to the survey questions about taxes and fees differed by socio-demographics, political characteristics, travel behavior, census region, and community type. For most survey questions, the variation in responses was less than 10 percentage points across these characteristics (e.g., comparing men vs. women, or people who driving different numbers of miles annually). Future analyses should consider multivariate models to further tease out potential differences by personal characteristics.

10. The personal characteristics most often associated with divergent views were age, political affiliation, and community type. For example, support for the gas tax and mileage fee options was higher among the youngest group (18 to 25 years old) than the older groups. Also, people living in urban communities were more likely to support the gas tax and mileage fee options than those living in rural communities. 


\section{APPENDIX A: SURVEY QUESTIONNAIRE AND TOPLINE RESULTS}

This appendix presents the survey questionnaire and results for the 2020 survey.

The results have been weighted to match the Census Bureau's 2014 - 2018 American Community Survey five-year estimates with respect to gender, race, Hispanic ethnicity, education level, annual household income, and age. ${ }^{15}$

The authors removed missing and refused responses from the dataset before calculating the response rates.

Note that some categories in the tables do not sum to $100 \%$ due to rounding.

Researchers at the Mineta Transportation Institute, San Jose State University, are conducting a survey to gather your thoughts about transportation in the United States. Your opinions are very important, no matter how much or little you travel. Public officials can use the survey results to shape transportation services in communities throughout the country. The survey takes about 10 minutes and is anonymous. Your participation is completely voluntary. You can refuse to participate or stop the survey at any time without any negative effect on your relations with San Jose State University. If you participate, there are no anticipated risks to you and no anticipated benefits other than the satisfaction of sharing your views with the researchers. For more information about the study, contact Professor Asha W. Agrawal at asha.weinstein.agrawal@sjsu.edu. By agreeing to participate in the study, it is implied that you have read and understand the above information. Please do not write any identifying information on the survey/questionnaire.

We are interested in your opinions about the transportation system. The "transportation system" means local streets and roads, highways, and public transit services like buses, light rail, and trains.

Q1. In your community, how is the quality of:

\begin{tabular}{|c|c|c|c|c|c|}
\hline & $\begin{array}{c}\text { Very } \\
\text { good } \\
(\%)\end{array}$ & $\begin{array}{c}\text { Somewhat } \\
\text { good } \\
(\%)\end{array}$ & $\begin{array}{c}\text { Somewhat } \\
\text { bad } \\
(\%)\end{array}$ & $\begin{array}{l}\text { Very } \\
\text { bad } \\
(\%)\end{array}$ & $\begin{array}{c}\text { Not sure / } \\
\text { doesn't apply } \\
(\%)\end{array}$ \\
\hline Interstates, highways, and freeways & 25 & 50 & 17 & 5 & 3 \\
\hline Local streets and roads & 19 & 44 & 25 & 10 & 2 \\
\hline Bicycle and pedestrian facilities & 19 & 39 & 22 & 8 & 12 \\
\hline Public transit (bus, rail, etc.) & 18 & 37 & 20 & 10 & 15 \\
\hline
\end{tabular}

Q2. How concerned are you about traffic congestion in your community?

\begin{tabular}{lc}
\hline & $(\%)$ \\
\hline Very concerned & 34 \\
Somewhat concerned & 42 \\
Not at all concerned & 24 \\
\hline
\end{tabular}


The next questions ask for your opinion about what government can do to improve transportation in the United States.

Q3. How important are the following transportation-related goals for the United States?

\begin{tabular}{lccc}
\hline & $\begin{array}{c}\text { Very } \\
\text { important } \\
(\%)\end{array}$ & $\begin{array}{c}\text { Somewhat } \\
\text { important } \\
(\%)\end{array}$ & $\begin{array}{c}\text { Not } \\
\text { important } \\
(\%)\end{array}$ \\
\hline Reduce traffic congestion & 62 & 33 & 5 \\
Reduce crashes and improve safety & 74 & 23 & 3 \\
Reduce health impacts caused by air pollution from cars and trucks & 60 & 33 & 7 \\
Reduce greenhouse gas emissions from transportation sources that & 56 & 34 & 11 \\
contribute to climate change & & & \\
Maintain and improve roads, streets, highways, and bridges & 75 & 23 & 2 \\
Maintain and improve public transit (bus, light-rail, ferry, etc.) & 58 & 35 & 6 \\
Make it more convenient to go places without driving (bus, walking, bike, etc.) & 52 & 40 & 8 \\
\hline
\end{tabular}

Q4. As you may be aware, the federal government charges a gas tax and spends the money collected for transportation. Listed below are different ways the government could spend that money to improve the transportation system. How much of a priority should each one be?

\begin{tabular}{lcccc}
\hline & $\begin{array}{c}\text { High } \\
(\%)\end{array}$ & $\begin{array}{c}\text { Medium } \\
(\%)\end{array}$ & $\begin{array}{c}\text { Low } \\
(\%)\end{array}$ & $\begin{array}{c}\text { Not at all } \\
(\%)\end{array}$ \\
\hline Build/improve sidewalks & 42 & 40 & 14 & 4 \\
Provide discounted public transit fares for low-income people & 47 & 35 & 13 & 5 \\
Develop programs that encourage people to switch from & 34 & 41 & 18 & 7 \\
driving their cars to walking, biking, or using transit & & & & \\
Provide financial incentives for people to purchase electric & 32 & 35 & 20 & 13 \\
vehicles & & & & 6 \\
Build/improve bike lanes and bike paths & 34 & 41 & 20 & 3 \\
Use advanced technologies to reduce congestion and & 47 & 40 & 10 & \\
increase reliability & & & & 9 \\
Install more charging stations for electric vehicles & 29 & 37 & 24 & 15 \\
Add more frequent public transit service on existing routes & 41 & 39 & 11 & 3 \\
Improve safety for pedestrians and bicyclists & 51 & 36 & 13 & 4 \\
Expand public transit service into new areas not already & 45 & 38 & & \\
served & & & 5 & 2 \\
Maintain local streets and roads & 62 & 31 & 16 & 4 \\
Build/widen local roads and streets & 38 & 42 & 11 & 4 \\
Build/widen interstates, highways, and freeways & 44 & 41 & 4 & 2 \\
Maintain interstates, highways, and freeways & 66 & 28 & 9 & 4 \\
Maintain public transit (rail, buses, etc.) & 50 & 37 &
\end{tabular}


Q5. Here is the same list of transportation purposes that the federal government could spend the gas tax money on. Select the three you think are most important.

\begin{tabular}{lc}
\hline & Selected at top 3 (\%) \\
\hline Build/improve sidewalks & 22 \\
Provide discounted public transit fares for low-income people & 23 \\
Develop programs that encourage people to switch from driving their cars to walking, & 17 \\
biking, or using transit & 14 \\
Provide financial incentives for people to purchase electric vehicles & 11 \\
Build/improve bike lanes and bike paths & 24 \\
Use advanced technologies to reduce congestion and increase reliability & 8 \\
Install more charging stations for electric vehicles & 15 \\
Add more frequent public transit service on existing routes & 15 \\
Improve safety for pedestrians and bicyclists & 20 \\
Expand public transit service into new areas not already served & 37 \\
Maintain local streets and roads & 14 \\
Build/widen local roads and streets & 18 \\
Build/widen interstates, highways, and freeways & 33 \\
Maintain interstates, highways, and freeways & 15 \\
Maintain public transit (rail, buses, etc.) & 2 \\
\hline
\end{tabular}

Q6. In the last 30 days, which types of transportation have you used? Check all that apply.

\begin{tabular}{lc}
\hline & Used in last 30 days (\%) \\
\hline Drive yourself (car, truck, motorcycle, etc.) & 76 \\
Ride as a passenger in a personal vehicle (exclude trips in taxis, rideshare like & 40 \\
Uber/Lyft, etc.) & 24 \\
Public transit (bus, light-rail, ferry, etc.) & 7 \\
Taxi & 16 \\
Ridesharing service like Uber or Lyft & 45 \\
Walk & 12 \\
Bicycle & 2 \\
Electric kick-scooter, skateboard, or other small device & 2 \\
Airplane & 6 \\
Other & 1 \\
\hline
\end{tabular}

Q7. About how many miles did you, personally, drive during the past 12 months in all motorized vehicles? If you work, include the commute to and from work, but not any miles driven while on the job.

\begin{tabular}{lc}
\hline & $(\%)$ \\
\hline Don't drive & 15 \\
1 to 5,000 miles & 31 \\
5,001 to 7,500 miles & 18 \\
7,500 to 10,000 miles & 12 \\
10,001 to 12,500 miles & 10 \\
12,501 to 15,000 miles & 7 \\
15,001 to 20,000 miles & 4 \\
20,0001 or more & 4 \\
\hline
\end{tabular}


Now think about the vehicle you drove the most in the past 12 months, to get around for personal reasons like shopping, commuting to work, or vacation trips.

Q8. Is this vehicle a $100 \%$ all-electric vehicle? [If yes, skip to Q11]

\begin{tabular}{lc}
\hline & $(\%)$ \\
\hline Yes & 2 \\
No & 98 \\
\hline
\end{tabular}

Q9. How many miles per gallon does the vehicle get? Your best guess is fine.

\begin{tabular}{lc}
\hline & $(\%)$ \\
\hline Less than $19 \mathrm{mpg}$ & 19 \\
20 to $30 \mathrm{mpg}$ & 46 \\
More than $30 \mathrm{mpg}$ & 18 \\
Don't know & 17 \\
\hline
\end{tabular}

Q10. For that vehicle, how much to you spend buying fuel (gas, diesel, etc.) in a typical month?

\begin{tabular}{lc}
\hline & $(\%)$ \\
\hline$\$ 1$ to $\$ 50$ & 32 \\
$\$ 51$ to $\$ 100$ & 35 \\
$\$ 101$ to $\$ 150$ & 20 \\
$\$ 151$ to $\$ 200$ & 9 \\
$\$ 201$ or more & 4 \\
\hline
\end{tabular}

Q11. In the past 30 days, have you paid a toll to drive on a bridge, tunnel, or road?

\begin{tabular}{lc}
\hline & $(\%)$ \\
\hline Yes & 28 \\
No & 72 \\
\hline
\end{tabular}

There are many ways the U.S. Congress could raise money to pay for maintaining and improving the transportation system. The next few questions ask your opinion about some of these options. In each case, assume that the money collected would be spent only for transportation purposes.

Q12. Right now the federal government collects a tax of $18 \phi$ per gallon when people buy gasoline. One idea to raise money for transportation is to increase the federal gas tax by $10 \phi$ a gallon, from $18 \phi$ to $28 \phi$. Would you support or oppose this gas tax increase?

\begin{tabular}{lc}
\hline & $(\%)$ \\
\hline Strongly support & 14 \\
Somewhat support & 30 \\
Somewhat oppose & 26 \\
Strongly oppose & 30 \\
\hline
\end{tabular}


Q13. Now, imagine that the U.S. Congress decided that the best option to raise money for transportation is to increase the federal gas tax by ten cents per gallon. Would you support or oppose the gas tax increase if the new money were spent only on the following types of projects?

\begin{tabular}{lcccc}
\hline & $\begin{array}{c}\text { Strongly } \\
\text { support } \\
(\%)\end{array}$ & $\begin{array}{c}\text { Somewhat } \\
\text { support } \\
(\%)\end{array}$ & $\begin{array}{c}\text { Somewhat } \\
\text { oppose } \\
(\%)\end{array}$ & $\begin{array}{c}\text { Strongly } \\
\text { oppose } \\
(\%)\end{array}$ \\
\hline $\begin{array}{l}\text { Reduce local air pollution caused by the transportation system } \\
\text { Reduce the transportation system's contribution to global }\end{array}$ & 23 & 33 & 22 & 22 \\
warming & 30 & 32 & 19 & 20 \\
Maintain streets, roads, and highways & 42 & 33 & 13 & 12 \\
Reduce accidents and improve safety & 41 & 32 & 13 & 14 \\
Reduce traffic congestion & 37 & 34 & 15 & 14 \\
\hline
\end{tabular}

Q14. Some people say that money from gas taxes should only be spent on roads and highways, since drivers pay the tax. Other people say gas tax money should be used to pay for public transit in addition to roads and highways, because transit helps reduce traffic congestion and wear-and-tear on the roads. Would you support or oppose spending some gas tax money on public transit?

\begin{tabular}{lc}
\hline & $(\%)$ \\
\hline Support & 71 \\
Oppose & 29 \\
\hline
\end{tabular}

Note on Q14: Half of respondents received the question as worded here, and the other half received the question with the two statements in reverse order: Some people say gas tax money should be used to pay for public transit in addition to roads and highways, because transit helps reduce traffic congestion and wear-and-tear on the roads. Other people say that money from gas taxes should only be spent on roads and highways, since drivers pay the tax. Would you support or oppose spending some gas tax money on public transit?

Now, imagine that the US Congress decides to replace the gas tax with a mileage fee of one penny per mile driven. That means someone driving 10,000 miles a year would pay $\$ 100$. Vehicles would have an electronic meter to keep track of the miles driven.

Q15. Would you support or oppose replacing the gas tax with such a mileage fee?

\begin{tabular}{lc}
\hline & $(\%)$ \\
\hline Strongly support & 15 \\
Somewhat support & 29 \\
Somewhat oppose & 22 \\
Strongly oppose & 33 \\
\hline
\end{tabular}


Q16. A variation on the mileage tax just described is to have the tax rate vary depending upon how much the vehicle pollutes. On average, vehicles would be charged $1 \phi$ per mile, but vehicles that pollute less would be charged less, and vehicles that pollute more would be charged more. Would you support or oppose this new mileage tax?

\begin{tabular}{lc}
\hline & $(\%)$ \\
\hline Strongly support & 15 \\
Somewhat support & 34 \\
Somewhat oppose & 23 \\
Strongly oppose & 28 \\
\hline
\end{tabular}

Q17. A different variation on the mileage fee concept is to replace the gas tax with a mileage fee of one penny per mile for all gas and diesel vehicles, but with a different rate for all-electric vehicles. What rate per mile do you think electric vehicles should pay?

\begin{tabular}{lc}
\hline & $(\%)$ \\
\hline The same rate as gas/diesel vehicles & 43 \\
Half the rate set for gas/diesel vehicles & 37 \\
Nothing (electric vehicles pay no fee) & 20 \\
\hline
\end{tabular}

Q18. Now imagine that the US Congress decides to keep the gas tax, but to add a new per-mile "Business Road-Use Fee" for miles that commercial vehicles drive on the job. (These vehicles would continue to pay the current gas tax, as well.) Would you support or oppose this new Business Road-Use Fee for the following types of commercial vehicles?

\begin{tabular}{lcccc}
\hline & $\begin{array}{c}\text { Strongly } \\
\text { support } \\
(\%)\end{array}$ & $\begin{array}{c}\text { Somewhat } \\
\text { support } \\
(\%)\end{array}$ & $\begin{array}{c}\text { Somewhat } \\
\text { oppose } \\
(\%)\end{array}$ & $\begin{array}{c}\text { Strongly } \\
\text { oppose } \\
(\%)\end{array}$ \\
\hline Delivery \& freight trucks & 21 & 33 & 25 & 21 \\
Taxis & 20 & 32 & 25 & 22 \\
Ridehailing vehicles & 20 & 32 & 27 & 21 \\
\hline
\end{tabular}

Q19. How much do you agree or disagree with the following statement? I'm already tracked everywhere I go through my phone, so having my mileage tracked for a mileage fee wouldn't really bother me.

\begin{tabular}{lc}
\hline & $(\%)$ \\
\hline Strongly agree & 17 \\
Somewhat agree & 28 \\
Somewhat disagree & 23 \\
Strongly disagree & 32 \\
\hline
\end{tabular}

Q20. Which statement is closer to your opinion?

\begin{tabular}{ll}
\hline & $(\%)$ \\
\hline A mileage fee is MORE fair than the gas tax because everyone pays the same for use of the roads, & 50 \\
regardless of vehicle fuel efficiency or vehicle type (electric vs. gas vehicles) \\
A mileage fee is LESS fair than the gas tax because the mileage fee doesn't give a break to people \\
who buy cleaner vehicles.
\end{tabular}


Q21. If Congress does create a federal mileage fee, how would you prefer to pay? Remember that the total amount you pay annually would be the same in each option.

\begin{tabular}{lc}
\hline & $(\%)$ \\
\hline Pay a bill that comes once a year & 23 \\
Pay a bill that comes once a month & 30 \\
Pay each time I purchase gas/diesel or charge an electric vehicle & 47 \\
\hline
\end{tabular}

Q22. As best you remember, when did the U.S. Congress last raise the federal gas tax?

\begin{tabular}{lc}
\hline & $(\%)$ \\
\hline 1 to 3 years ago & 20 \\
4 to 10 years ago & 14 \\
11 to 15 years ago & 6 \\
16 to 20 years ago & 2 \\
More than 20 years ago & 3 \\
Don't know & 55 \\
\hline
\end{tabular}

Q23. Now we have a question about the state where you live. As best you remember, when did your state government last raise the state gas tax?

\begin{tabular}{lc}
\hline & $(\%)$ \\
\hline 1 to 3 years ago & 30 \\
4 to 10 years ago & 14 \\
11 to 15 years ago & 4 \\
16 to 20 years ago & 1 \\
More than 20 years ago & 1 \\
Don't know & 30 \\
\hline
\end{tabular}




\section{ENDNOTES}

1. For the results of the first ten years of polling in this series, see Asha Weinstein Agrawal and Hilary Nixon, What Do Americans Think about Federal Transportation Tax Options? Results from a National Survey (San José, CA: Mineta Transportation Institute, June 2010), http://transweb.sjsu.edu/MTIportal/research/publications/ documents/2928_09-18.pdf; Asha Weinstein Agrawal and Hilary Nixon, What Do Americans Think About Federal Transportation Tax Options? Results from Year 2 of a National Survey (San José, CA: Mineta Transportation Institute, June 2011), http:// transweb.sjsu.edu/PDFs/research/Transportation_taxes_public_opinion_1031.pdf; Asha Weinstein Agrawal, Hilary Nixon, and Vinay Murthy, What Do Americans Think About Federal Tax Options to Support Public Transit, Highways, and Local Streets and Roads? Results from Year 3 of a National Survey (San José, CA: Mineta Transportation Institute, June 2012), http://transweb.sjsu.edu/PDFs/research/1128-american-surveyfederal-taxes-public-transit-highways-streets-roads.pdf; Asha Weinstein Agrawal and Hilary Nixon, What Do Americans Think About Federal Tax Options to Support Public Transit, Highways, and Local Streets and Roads? Results from Year 4 of a National Survey (San José, CA: Mineta Transportation Institute, June 2013), http://transweb. sjsu.edu/PDFs/research/1228-American-tax-poll-2013-public-transit-highways-streetsroads.pdf; Asha Weinstein Agrawal and Hilary Nixon, What Do Americans Think About Federal Tax Options to Support Public Transit, Highways, and Local Streets and Roads? Results from Year 5 of a National Survey (San José, CA: Mineta Transportation Institute, June 2014), http://transweb.sjsu.edu/PDFs/research/1328-road-tax-public-opinionpoll-2014.pdf; Asha Weinstein Agrawal and Hilary Nixon, What Do Americans Think About Federal Tax Options to Support Public Transit, Highways, and Local Streets and Roads? Results from Year 6 of a National Survey (San José, CA: Mineta Transportation Institute, June 2015), http://transweb.sjsu.edu/PDFs/research/1428-road-tax-publicopinion-poll-2015.pdf; Asha Weinstein Agrawal and Hilary Nixon, What Do Americans Think About Federal Tax Options to Support Public Transit, Highways, and Local Streets and Roads? Results from Year 7 of a National Survey (San José, CA: Mineta Transportation Institute, June 2016), https://transweb.sjsu.edu/sites/default/files/1528road-and-transit-taxes-public-opinion-survey-2016.pdf; Asha Weinstein Agrawal and Hilary Nixon, What Do Americans Think About Federal Tax Options to Support Public Transit, Highways, and Local Streets and Roads? Results from Year 8 of a National Survey (San José, CA: Mineta Transportation Institute, June 2017), http://transweb. sjsu.edu/PDFs/research/1728-what-do-americans-think-about-federal-tax-optionsto-support-public-transit-highways-and-local-streets-and-roads.pdf; Asha Weinstein Agrawal and Hilary Nixon, What Do Americans Think About Federal Tax Options to Support Public Transit, Highways, and Local Streets and Roads? Results from Year 9 of a National Survey (San José, CA: Mineta Transportation Institute, June 2018), http://transweb.sjsu.edu/research/1828-Survey-Transportation-Tax-Year-Nine; and Asha Weinstein Agrawal and Hilary Nixon, What Do Americans Think About Federal Tax Options to Support Transportation? Results from Year 10 of a National Survey (San José, CA: Mineta Transportation Institute, June 2019), https://transweb.sjsu.edu/ research/1927-Survey-Transportation-Tax-Year-Ten.

2. The current federal tax on gasoline is $18.4 \phi$ per gallon, but respondents were told that it was $18 \phi$ per gallon, to make the survey simpler to understand. 
3. The description of the mileage fee options in the 2020 and 2019 surveys is slightly different from the description presented in previous years' surveys.

4. Valerie M. Sue and Lois A. Ritter, Conducting Online Surveys, 2nd edition (Sage Publications, 2012), https://dx.doi.org/10.4135/9781506335186.

5. Monica Anderson, et al., " $10 \%$ of Americans Don't Use the Internet; Who Are They?" Pew Research Center, April 22, 2019, https://www.pewresearch.org/facttank/2019/04/22/some-americans-dont-use-the-internet-who-are-they/.

6. Pew Research Center, Collecting Survey Data (no date), https://www.pewresearch. org/methods/u-s-survey-research/collecting-survey-data/.

7. Sue and Ritter, 2012.

8. Hilary Nixon and Asha Weinstein Agrawal, Do Americans' Opinions About Federal Transportation Tax Options Depend on Survey Mode? A Comparison of Results from Telephone and Online Surveys (San Jose: Mineta Transportation Institute, April 2018), http://transweb.sjsu.edu/research/Do-Americans-Opinions-About-FederalTransportation-Tax-Options-Depend-Survey-Mode.

9. Courtney Kennedy and Claudia Deane, "What Our Transition to Online Polling Means for Decades of Phone Survey Trends," Pew Research Center, February 27, 2019, https://www.pewresearch.org/fact-tank/2019/02/27/what-our-transition-to-onlinepolling-means-for-decades-of-phone-survey-trends/.

10. The U.S. Census Bureau's 2014-2018 American Community Survey 5-Year Public Use Microdata Samples were downloaded from data.census.gov.

11. Agrawal and Nixon, 2019.

12. For more information about the use of $p$-values in scientific research, see: American Statistical Association, "Statement on Statistical Significant and P-values," ASA News, March 7, 2016, https://www.amstat.org/newsroom/pressreleases/P-ValueStatement.pdf.

13. Nixon and Agrawal, 2018.

14. Half of respondents received the question as worded here, and the other half received the question with the two statements in reverse order: "Some people say gas tax money should be used to pay for public transit in addition to roads and highways, because transit helps reduce traffic congestion and wear-and-tear on the roads. Other people say that money from gas taxes should only be spent on roads and highways, since drivers pay the tax. Would you support or oppose spending some gas tax money on public transit?"

15. The U.S. Census Bureau's 2014-2018 American Community Survey 5-Year Public Use Microdata Samples were downloaded from data.census.gov. 


\section{BIBLIOGRAPHY}

Agrawal, Asha Weinstein, and Hilary Nixon. What Do Americans Think About Federal Transportation Tax Options? Results from a National Survey. San José, CA: Mineta Transportation Institute, June 2010. http://transweb.sjsu.edu/MTIportal/ research/publications/documents/2928_09-18.pdf.

What Do American Think About Federal Transportation Tax Options? Results from Year 2 of a National Survey. San José, CA: Mineta Transportation Institute, June 2011. http://transweb.sjsu.edu/PDFs/research/Transportation_taxes_public opinion_1031.pdf.

What Do Americans Think About Federal Transportation Tax Options? Results from Year 4 of a National Survey. San José, CA: Mineta Transportation Institute, June 2013. http://transweb.sjsu.edu/PDFs/research/1228-American-tax-poll-2013public-transit-highways-streets-roads.pdf.

What Do Americans Think About Federal Tax Options to Support Public Transit, Highways, and Local Streets and Roads? Results from Year Five of a National Survey. San José, CA: Mineta Transportation Institute, June 2014. http://transweb. sjsu.edu/PDFs/research/1328-road-tax-public-opinion-poll-2014.pdf.

What Do Americans Think About Federal Tax Options to Support Public Transit, Highways, and Local Streets and Roads? Results from Year Six of a National Survey. San José, CA: Mineta Transportation Institute, June 2015. http://transweb. sjsu.edu/PDFs/research/1428-road-tax-public-opinion-poll-2015.pdf.

What Do Americans Think About Federal Tax Options to Support Public Transit, Highways, and Local Streets and Roads? Results from Year Seven of a National Survey. San José, CA: Mineta Transportation Institute, June 2016. http://transweb. sjsu.edu/PDFs/research/1528-road-and-transit-taxes-public-opinion-survey-2016. pdf.

What Do Americans Think About Federal Tax Options to Support Public Transit, Highways, and Local Streets and Roads? Results from Year Eight of a National Survey. San José, CA: Mineta Transportation Institute, June 2017. http://transweb. sjsu.edu/PDFs/research/1728-what-do-americans-think-about-federal-tax-optionsto-support-public-transit-highways-and-local-streets-and-roads.pdf.

What Do Americans Think About Federal Tax Options to Support Public Transit, Highways, and Local Streets and Roads? Results from Year 9 of a National Survey. San José, CA: Mineta Transportation Institute, June 2018. http://transweb. sjsu.edu/research/1828-Survey-Transportation-Tax-Year-Nine.

What Do Americans Think About Federal Tax Options to Support Transportation? Results from Year 10 of a National Survey. San José, CA: Mineta Transportation Institute, June 2019. https://transweb.sjsu.edu/research/1927-SurveyTransportation-Tax-Year-Ten. 
Agrawal, Asha Weinstein, Hilary Nixon, and Ashley M. Hooper. Public Perception of Mileage-Based User Fees, NCHRP Synthesis 487. Washington, D.C.: Transportation Research Board, 2016.

Agrawal, Asha Weinstein, Hilary Nixon, and Vinay Murthy. What Do American Think About Federal Transportation Tax Options? Results from Year 3 of a National Survey. San José, CA: Mineta Transportation Institute, June 2012. http://transweb. sjsu.edu/PDFs/research/1128-american-survey-federal-taxes-public-transithighways-streets-roads.pdf.

American Association for Public Opinion Research. "Response Rates: An Overview." No date. http://www.aapor.org/Education-Resources/For-Researchers/Poll-SurveyFAQ/Response-Rates-An-Overview.aspx.

American Statistical Association. "Statement on Statistical Significant and P-Values." ASA News, March 7, 2016. https://www.amstat.org/newsroom/pressreleases/PValueStatement.pdf.

Anderson, Monica, et al. "10\% of Americans Don't Use the Internet; Who Are They?" Pew Research Center, April 22, 2019. https://www.pewresearch.org/facttank/2019/04/22/some-americans-dont-use-the-internet-who-are-they/.

Kennedy, Courtney, and Claudia Deane. "What Our Transition to Online Polling Means for Decades of Phone Survey Trends." Pew Research Center, February 27, 2019. https://www.pewresearch.org/fact-tank/2019/02/27/what-our-transition-to-onlinepolling-means-for-decades-of-phone-survey-trends/.

Nixon, Hilary, and Asha Weinstein Agrawal. Do Americans' Opinions About Federal Transportation Tax Options Depend on Survey Mode? A Comparison of Results from Telephone and Online Surveys. San Jose: Mineta Transportation Institute, April 2018. http://transweb.sjsu.edu/research/Do-Americans-Opinions-AboutFederal-Transportation-Tax-Options-Depend-Survey-Mode.

Pew Research Center. "Collecting Survey Data." No date. https://www.pewresearch.org/ methods/u-s-survey-research/collecting-survey-data/.

Ruggles, Steven, Sarah Flood, Ronald Goeken, Josiah Grover, Erin Meyer, Jose Pacas and Matthew Sobek. IPUMS USA: Version 10.0 [dataset]. Minneapolis, MN: IPUMS, 2020. https://doi.org/10.18128/D010.V10.0.

U.S. Census Bureau. "American FactFinder." No date. https://factfinder.census.gov/ faces/nav/jsf/pages/searchresults.xhtml?refresh=t.

_. "Census Regions and Divisions of the United States." No date. https://www2. census.gov/geo/pdfs/maps-data/maps/reference/us_regdiv.pdf.

U.S. Energy Information Administration. "U.S. Gasoline Prices Increased in 2017." January 4, 2018. https://www.eia.gov/todayinenergy/detail.php?id=34392. 
. "U.S. Household Spending for Gasoline is Expected to Remain Below $\$ 2,000$ in 2017." October 6, 2017. https://www.eia.gov/todayinenergy/detail.php?id=33232.

U.S. Environmental Protection Agency. "SmartWay Vehicle Thresholds MY 2015." January 2014. https://nepis.epa.gov/Exe/ZyPURL.cgi?Dockey=P100HP2R.TXT.

Sue, Valerie M., and Lois A. Ritter. Conducting Online Surveys, 2nd Edition. Sage Publications, 2012. https://dx.doi.org/10.4135/9781506335186. 


\section{ABOUT THE AUTHORS}

\section{ASHA WEINSTEIN AGRAWAL, PH.D.}

Dr. Agrawal is the Director of the MTI National Transportation Finance Center and also professor of Urban and Regional Planning at San José State University. Her research and teaching interests in transportation policy and planning include transportation finance, bicycle and pedestrian planning, and travel survey methods. She also works in the area of transportation history. She has a B.A. from Harvard University in Folklore and Mythology, an M.Sc. from the London School of Economics and Political Science in Urban and Regional Planning, and a Ph.D. from the University of California, Berkeley, in City and Regional Planning.

\section{HILARY NIXON, PH.D.}

Dr. Nixon is Deputy Executive Director for the Mineta Transportation Institute and a faculty member in the M.S. Transportation Management program at San José State University. She specializes in transportation and environmental planning and policy, and her research focuses primarily on the factors that influence pro-environmental behavior and the relationship between transportation and the environment. She earned a B.A. from the University of Rochester and a Ph.D. in Planning, Policy and Design from the University of California, Irvine. 


\author{
Founder, Honorable \\ Norman Mineta (Ex-Officio) \\ Secretary (ret.), \\ US Department of Transportation \\ Chair, \\ Abbas Mohaddes (TE 202I) \\ President \& COO \\ Econolite Group Inc. \\ Vice Chair, \\ Will Kempton (TE 2022) \\ Retired \\ Executive Director, \\ Karen Philbrick, PhD \\ (Ex-Officio) \\ Mineta Transportation Institute \\ San José State University \\ Richard Anderson \\ (Ex-Officio) \\ President \& CEO \\ Amtrak \\ David Castagnetti (TE 202 I) \\ Co-Founder \\ Mehlman Castagnetti \\ Rosen \& Thomas \\ Maria Cino (TE 202 I) \\ Vice President \\ America \& U.S. Government \\ Relations Hewlett-Packard Enterprise
}

\author{
Grace Crunican* \\ (TE 2022) \\ Retired
}

Donna DeMartino (TE 202I)

General Manager \& CEO

San Joaquin Regional Transit District

Nuria Fernandez* (TE 2020)

General Manager \& CEO

Santa Clara Valley

Transportation Authority (VTA)

John Flaherty (TE 2020)

Senior Fellow

Silicon Valley American

Leadership Form

Rose Guilbault (TE 2020)

Board Member

Peninsula Corridor

Joint Powers Board

Ian Jefferies (Ex-Officio)

President \& CEO

Association of American Railroads

Diane Woodend Jones

(TE 2022)

Principal \& Chair of Board

Lea + Elliott, Inc.
Therese McMillan

(TE 2022)

Executive Director

Metropolitan Transportation

Commission (MTC)

Bradley Mims (TE 2020)

President \& CEO

Conference of Minority

Transportation Officials (COMTO)

Jeff Morales (TE 2022)

Managing Principal

InfraStrategies, LLC

Dan Moshavi, PhD

(Ex-Officio)

Dean, Lucas College and

Graduate School of Business

San José State University

Takayoshi Oshima (TE 202 I)

Chairman \& CEO

Allied Telesis, Inc.

Toks Omishakin

(Ex-Officio)

Director

California Department of

Transportation (Caltrans)
Paul Skoutelas (Ex-Officio)

President \& CEO

American Public Transportation

Association (APTA)

Dan Smith (TE 2020)

President

Capstone Financial Group, Inc.

Beverley Swaim-Staley (TE 2022)

President

Union Station Redevelopment

Corporation

\section{Jim Tymon (Ex-Officio)}

Executive Director

American Association of

State Highway and Transportation

Officials (AASHTO)

\section{Larry Willis (Ex-Officio)}

President

Transportation Trades

Dept., AFL-CIO

$(\mathrm{TE})=$ Term Expiration

* = Past Chair, Board of Trustees

\section{Directors}

Karen Philbrick, Ph.D.

Executive Director

Hilary Nixon, Ph.D.

Deputy Executive Director

\section{Asha Weinstein Agrawal,}

\section{Ph.D.}

Education Director

National Transportation Finance

Center Director

\section{Brian Michael Jenkins}

National Transportation Security

Center Director

\title{
Research Associates Policy Oversight Committee
}

Jan Botha, Ph.D.

Civil \& Environmental Engineering

San José State University

Katherine Kao Cushing,

\section{Ph.D.}

Enviromental Science

San José State University

Dave Czerwinski, Ph.D. Marketing and Decision Science San José State University
Frances Edwards,

Ph.D.

Political Science

San José State University

Taeho Park, Ph.D.

Organization and Management

San José State University

\section{Christa Bailey}

Martin Luther King, Jr. Library

San José State University

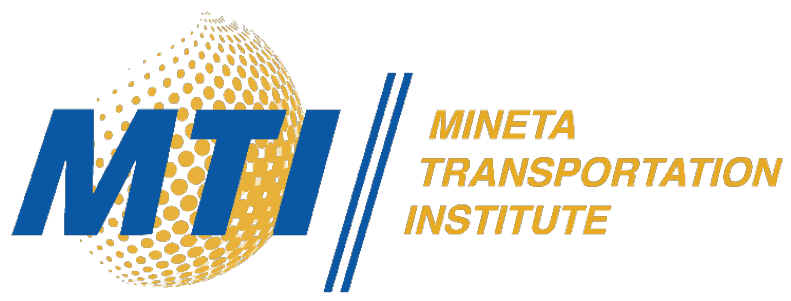

